IZA DP No. 9500

The Impact of Missionary Type on the English Language Proficiency and Earnings of Immigrants

Nicholas Larsen

Barry R. Chiswick

November 2015 


\title{
The Impact of Missionary Type on the English Language Proficiency and Earnings of Immigrants
}

\author{
Nicholas Larsen \\ Eastern Washington University \\ Barry R. Chiswick \\ George Washington University \\ and IZA
}

\section{Discussion Paper No. 9500 \\ November 2015}

\author{
IZA \\ P.O. Box 7240 \\ 53072 Bonn \\ Germany \\ Phone: +49-228-3894-0 \\ Fax: +49-228-3894-180 \\ E-mail: iza@iza.org
}

\begin{abstract}
Any opinions expressed here are those of the author(s) and not those of IZA. Research published in this series may include views on policy, but the institute itself takes no institutional policy positions. The IZA research network is committed to the IZA Guiding Principles of Research Integrity.

The Institute for the Study of Labor (IZA) in Bonn is a local and virtual international research center and a place of communication between science, politics and business. IZA is an independent nonprofit organization supported by Deutsche Post Foundation. The center is associated with the University of Bonn and offers a stimulating research environment through its international network, workshops and conferences, data service, project support, research visits and doctoral program. IZA engages in (i) original and internationally competitive research in all fields of labor economics, (ii) development of policy concepts, and (iii) dissemination of research results and concepts to the interested public.
\end{abstract}

IZA Discussion Papers often represent preliminary work and are circulated to encourage discussion. Citation of such a paper should account for its provisional character. A revised version may be available directly from the author. 
IZA Discussion Paper No. 9500

November 2015

\section{ABSTRACT}

\section{The Impact of Missionary Type on the English Language Proficiency and Earnings of Immigrants}

This paper analyzes the impact of missionary activity on English language proficiency and labor market earnings of all immigrants to the United States by using the pooled files of the American Community Survey (2005-09). We consider the colonial heritage of the origin country to determine if it is a missionary effect or an effect of colonial rule. Our results suggest immigrants from countries with a high concentration of Protestant missionaries tend to exhibit higher levels of English proficiency and earnings compared to Catholic missionaries. Furthermore, a higher proficiency in English enhances earnings. One of the important implications of the findings in this paper is that a "missionary variable" often used in other studies is too aggregate and may mask important findings because of strikingly different effects of Protestant and Catholic activities.

JEL Classification: F22, J61, J31, J24, Z12

Keywords: immigrants, Protestant, Catholic, missionaries, earnings, schooling,

English language, proficiency, American Community Survey

Corresponding author:

Barry R. Chiswick

Department of Economics

George Washington University

2115 G Street, NW

Monroe Hall 340

Washington, DC 20052

USA

E-mail: brchis@uic.edu 


\section{Introduction}

Recent research shows missionary activity of different denominations matter in their affect on economic outcomes within a developing country, but the economic impact of missionary denomination on outcomes of immigrants from those countries remains largely unexplored. Woodberry (2004, 2007, and 2012) found that missionary activity could have a positive impact on economic development—especially in terms of education, gender equality, and democracy—when the missionary activity focuses on investing in the human capital of the populace. Following the introduction of Christian missionaries to Ghana and Nigeria—as opposed to Northern African countries that are primarily Islamic — educational attainment increased tremendously because $97 \%$ of the total student population were enrolled in missionary schools (Berman 1974 and Nunn 2012). Any investment missionaries make in the education of people within a developing country has been shown to persist over a long period of time (Woodberry 2004).

Substantial differences exist between the method Protestant and Catholic missionaries use to spread their ministries. These differences have been found to affect educational attainment within these countries (Nunn 2012). Protestant missionaries focus more heavily on teaching the congregation or parishioners to read the Bible-oftentimes in English—than Catholic missionaries that focus more on preaching-sometimes in Latin - to spread their message (Woodberry 2007). Both denominations built schools and printing presses, but the efforts of Catholic missionaries were hindered as they had a limited focus and were isolated primarily among the elite (Woodberry 2012). This difference has lead to greater education attainment, and longer lasting effects, for Protestant missionaries compared to Catholic missionaries (Woodberry 2010 and Nunn 2012). Grier (1997) echoes 
the importance of this difference by finding a greater positive correlation between Protestant religion adherence within a country and economic growth compared to Catholic religion adherence.

As of yet, the differences in missionary denominations' affect on economic outcomes of immigrants in the destination have remained unexplored. By investing more heavily in the human capital of the people in the origin, Protestant missionaries are increasing the benefits of migration to the US as migrants gain more familiarity with English, western culture, and have an increased literacy rate. This should increase the likelihood of migration, and having a better ability to communicate upon arrival should shorten the immigrants' time to assimilation into the US labor market.

This paper focuses on the human capital investments and labor market success of people that have immigrated to the US. We use English language proficiency as one measure of their investment in human capital and earnings as the measure of labor market success. From Table 1, we observe the US historically sends significantly more missionaries than any other country. Of the missionaries in 1980, 61 percent of US missionaries were Protestant (Barrett 1982).

Table 1 about here

International migration streams are generally composed of a relatively small proportion of the origin population, of which these migrants are motivated primarily by economic concerns. These migrants have the characteristics, whether measurable or not, for being successful in adjusting to conditions within the destination country and are “positively selected” for economic success in the destination (Chiswick 2000). These migrants are positively self-selected by having the greatest economic benefit from 
migrating. That is, the most able would tend to receive a greater return on their decision to leave home, family and friends, and their familiar surroundings, than those who remain behind. Depending on time and place, some of this positive selectivity also arises from the destination government's immigration policy—selecting immigrants on the basis of health status, language fluency, literacy or educational attainment, work skills or some other characteristics that are deemed desirable.

The US decennial Census "long form" survey, which has been the basis of much research on the characteristics of immigrants and other demographic groups, was discontinued after the 2000 Census. While the long form provided the large sample that generated a sufficient number of observations for the study of small demographic groups and small geographic areas, it was only a once in a decade snap-shot of the American population. Moreover, collecting and processing these data necessitated a large temporary spike in Census Bureau staffing and expenditures. While the decennial Census continues with a very small set of questions, the American Community Survey (ACS) has replaced the long form. The ACS is a large monthly survey of randomly selected households that when aggregated across the months and years, provides for the continuous measurement of the population. Moreover, by spreading out the workload over a decade, the Census Bureau is able to mitigate the spike in activity associated with the "long form" sample. Although some questions vary over time in the ACS, it essentially replicates the questions that had been asked in the Census long form. As a result, the ACS provides a continuous record of the demographic and economic features of American households, which provides sufficiently large sample sizes for the study of small demographic groups. 
The ACS, as did the 2000 Census long forms, includes basic demographic questions (e.g., year of birth, gender, marital status, place of residence), labor market questions (e.g., employment, occupation, industry, earnings, weeks worked), educational attainment, and immigrant-related questions (e.g., country of birth, year of immigration to the U.S., and U.S. citizenship). As with the 2000 Census, it does not ask certain questions of relevance for immigrants, such as visa status at entry, current visa status for those not U.S. citizens, country of last permanent residence before U.S. entry, parental birthplace, and the respondent's religion.

This paper uses the five year cumulative 2005-09 American Community Survey (ACS) to examine the linguistic adjustment to English and labor market earnings of adult male and female immigrants in the United States. The focus of this analysis is on the likelihood of exposure to missionary schooling in their country of origin.

\section{The Dependent Variables}

The first dependent variable is this paper is the dichotomous variable for English language proficiency. In the absence of alternative data on destination language proficiency in immigrant receiving countries, self-reported proficiency has become the standard used in the literature on the economics of language (Chiswick and Miller 2007). "Good English” is designated by unity if the respondent reports speaking only English at home, or, if another language is spoken, the respondent reports speaking English "very well” or "well." If English speaking ability is reported as "not well" or "not at all (or only a few words)" the good English variable is set equal to zero. 
The respondent's annual earnings are measured as the sum of last year's wage, salary and self-employment income. The logarithm of earnings, rather than earnings itself, is used by labor economists as the dependent variable in analyses of earnings. Using the natural logarithm of earnings, the coefficients of the explanatory variables have economic interpretations, and the regression equation residuals have nicer statistical properties (closer to a normal distribution and to being homoskedastic) (Mincer 1974). While wage and salary incomes cannot be negative, self-employment income can. Because natural logarithms cannot be taken of zero or negative numbers, annual earnings that sum to $\$ 1,000$ or less (including negative values) are assigned a value of $\$ 1,000$. Those who report zero earnings were presumably not in the labor market and are deleted from the data. The earnings data are adjusted for inflation so that the earnings are in 2009 dollars.

\section{The Econometric Models}

\section{(A) Language Proficiency Equation}

As in the previous studies of the English language adjustment of immigrants to the US, the explanatory variables include demographic and human capital variables in addition to the missionary variables (Chiswick and Miller 2007):

(1) Missionary - The type of schooling the respondent received in the origin is not known, but the missionary variable in the English language proficiency equation can test the effects of the prevalence of Protestant and Catholic missionary schooling in the origin on the English language proficiency of immigrants in the U.S. Even if the respondent did not attend a missionary school, a greater density of Protestant or Catholic missionaries would establish a climate in the educational system. The number of Protestant missionaries in 
1923 per 10,000 population in the country of birth, the number of foreign Catholic missionaries in 1923 per 10,000 population, or the summation of the Protestant missionaries and the Catholic missionaries is included in the regression analysis (Woodberry 2012). ${ }^{1}$ In the context of this paper, Catholic priests are treated as Catholic missionaries. Tests were conducted for interaction terms between the missionary variables and other explanatory variables, in particular schooling and duration in the destination, but these interactions are not included in the discussion.

(2) Age at Migration - Other variables the same, research in linguistics and the economics of language shows that immigrant destination language proficiency is lower with an older age at immigration. The age effect is steeper among youths and teenagers, but tends to level off among older immigrants. The ability to adapt to a new language appears to weaken at older ages.

(3) Schooling - Education is measured by years of schooling completed. Immigrants with more schooling have been found to be more proficient in the dominant language in the destination, perhaps because those with higher levels of intellectual ability are more proficient in learning new languages and attain more schooling. It may also be that those who attain higher levels of schooling in the origin are more likely to be exposed to the English language in school, and hence schooling level and English proficiency are positively related. The data do not identify the country in which schooling was obtained. It might be that schooling in the US is associated with greater English language proficiency,

\footnotetext{
${ }^{1}$ The correlation between Protestant and Catholic missionaries is 0.1915 ; indicating that the opposite signs in the regression equations is not indicative of multicollinearity.
} 
either because English proficiency is a prerequisite for US schooling, or because the US schooling experience enhances English proficiency.

(4) Years Since Migration - Duration in the destination measured in years is a simple measure of exposure to the language of the destination. The longer the duration, the more time there is to acquire destination language skills ("learning by living"), although it is expected that the greatest impact would occur in the early years, with the marginal effect diminishing as time passes. Hence, duration is treated as a quadratic variable.

(5) Married Spouse Present - A marital status variable is included in the model to establish whether being married (or in a cohabitating relationship) is associated with greater proficiency. It also indicates whether the marriage effect differs by gender. If marriage encourages specialization in labor market vs. home production activities, it may enhance the English proficiency of men, but decrease that of women.

(6) Children (kids) -The presence of a child in the household is entered in the language equation for women. Children are associated with a lower labor force participation rate for women and hence less of an incentive to acquire English language proficiency and less of an opportunity for exposure to English in the workplace.

(B) Earnings Equation:

The equation is modified in the analysis of earnings. A human capital earnings function is employed. The dependent variable is the natural logarithm of the sum of wage, salary and self-employment income in the previous year. The explanatory variables include:

(1) Missionary - The type of schooling the respondent received in the origin is not known, whether it is from a state school or a missionary school. The missionary variable in the 
earnings equation can test the effects of the prevalence of Protestant and Catholic missionary schooling in the origin on the earnings in the U.S. Even if the respondent did not attend a missionary school, a greater density of Protestant or Catholic missionaries would establish a climate in the educational system.

(2) Schooling - Years of schooling enters into the analysis as a measure of labor market skills.

(3) Labor Market Experience - Labor market experience (EXP) is not directly reported in the ACS, but the standard proxy for potential experience is used-years since leaving school, measured as age minus years of schooling minus five. Experience and its square are entered into the equation to account for the non-linear effect on earnings of labor market experience. Earnings increase with experience, but at a decreasing rate.

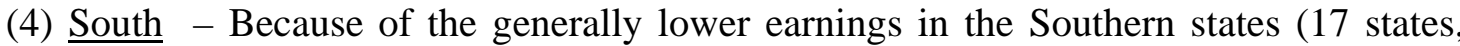
including the District of Columbia), a dichotomous variable for living in the South is included in the equation.

(5) English Proficiency (GoodEnglish) - The English language proficiency variable is included as a determinant of earnings. Immigrants more proficient in the destination language are expected to be more successful in finding a job, more likely to have a better match of their other skills to the job they find, and to be more productive on the job. Hence, they are expected to receive higher earnings.

(6) Years Since Migration - A longer duration in the destination is expected to result in more efficient labor market networks, and more skills relevant for the destination labor market. The effect will be non-linear (earnings increasing with duration at a decreasing 
rate) as greater investments in destination skills and knowledge are made in the earlier years, and diminish thereafter.

(7) Married Spouse Present - Marital status is included in the analysis as married men have a stronger labor market attachment than never-married men, and more able (higher earning) men are more likely to be successful in the marriage market (i.e., more likely to be married). Marriage is associated with a lower labor supply for women, hence less labor market experience in the past, and therefore lower earnings currently if employed. Those in a cohabitating relationship are treated as married.

(8) Children (kids) - The presence of one or more children in the household is associated with lower past female labor supply (that is not reflected in the labor market experience variable) and hence lower earnings for women.

(9) Weeks Worked -The variable for the natural logarithm of weeks worked is entered largely as a standardizing variable since the dependent variable is the natural logarithm of annual earnings. A coefficient greater than unity implies that those with higher weekly earnings work more weeks in the year. This may arise from those with higher weekly earnings wanting to work more (upward rising labor supply curve) or those who work more hours in a week also work more weeks in the year. Seasonal employment implies fewer weeks worked in the year, but a higher weekly wage during the weeks worked. Seasonal employment, by itself, would imply a coefficient on the log of weeks worked that is greater than zero but less than unity. Controlling for weeks worked, the coefficients of the other variables measure their partial effect on weekly earnings.

The analysis of English language proficiency and of earnings uses the combined American Community Survey 2005-09. The sample is limited to the males and females, 
age 25-64 years, who worked in the previous year and had earnings, and who were foreign born (i.e., born outside the US and its territories). The issue of selectivity of labor supply of women is not addressed in this paper. For each country of origin a variable was used to denote whether it was always independent (as were Thailand and Ethiopia for example) or whether their historical primary colonizer was US/UK, France, or Spain (Woodberry $2004)^{2}$.

\section{Data Analysis}

\section{(A) Descriptive Statistics}

Among the foreign-born adults who, from all countries of origin, worked in the previous year, the American Community Survey 2005-09 includes observations on 415,061 males and 325,280 females. The sample is smaller for females because of their lower labor force participation rate. Males have an inflation adjusted total earnings of $\$ 46,535$ compared to only $\$ 32,595$ for females (in 2009 dollars). Compared to men, the women on average have a greater level of both schooling, 12.8 years compared to 12.3 years, and English language proficiency, 73 percent defined as proficient compared to 70 percent. Additionally, the women who worked have slightly more years of labor market experience, but worked fewer weeks in the year than men. ${ }^{3}$

Having more schooling, greater proficiency in English, and more years since leaving school are all likely to have a positive effect on earnings for both males and females. With women having only slightly more years of schooling and years of experience

\footnotetext{
${ }^{2}$ See Statistical Appendix Table A-2, available upon request, for this breakdown.

3 The descriptive statistics for the variables (mean, standard deviation, minimum, and maximum) are reported in the Statistical Appendix, Table A-1, available on request.
} 
than men, a major difference in earnings between the two groups comes from the 49 percent of women having at least one child, which is expected to reduce their earnings.

Males are emigrating from countries were there are approximately 3.85 per 10,000 population more Catholic missionaries than there are Protestant missionaries. While for women the country they are emigrating from, the difference is only 3.25 per 10,000 population more Catholic missionaries.

\section{(B) Analysis of English Language Proficiency}

In the statistical analysis of English Language Proficiency (full regressions including interaction terms are reported in Tables A-3 through A-8 of the Statistical Appendix, available upon request), among both men and women, proficiency is more prevalent the higher the level of schooling, the longer the duration of residence in the US (increasing at a decreasing rate), the younger the age at migration, among those who are married (except for former UK/US colonies) and, among women, if there are no children in the household.

The survey year dichotomous variables (not shown in the Tables) are all negative in sign with very small coefficients and not statistically significant, with the exception of 2006, compared to the benchmark year $2009^{4}$. This means that there have been no trends in proficiency among immigrants in the ACS across the period (2005-09) when other variables, including duration in the US, are held constant.

For both males and females, an increase in the concentration of Catholic missionaries in the origin is associated with a lower English proficiency, while proficiency

\footnotetext{
${ }^{4}$ With 2009 serving as the benchmark, the coefficients, with t-statistics in parenthesis, for the dichotomous year variables were 0.0715 (17.02), 0.0707 (17.68), 0.0825 (21.15), and 0.0421 (10.53) for the years 2005, 2006, 2007, and 2008, respectively.
} 
is positively associated with an increase in the concentration of Protestant missionaries (Table 2). Besides a directionally different effect, the magnitude of the Protestant missionary effect is sizable (larger in absolute value) than Catholic missionaries for both males and females. For both males and females, among all immigrants, an increase in Protestant missionaries (per 10,000 population) is associated with an approximately 9.5 percentage point increase in the English language proficiency, while an increase in Catholic missionaries (per 10,000 population) is associated with an approximately 3.9 percentage point decrease.

Table 2

The effect of Catholic missionaries on English language proficiency appears to be negative in all cases, while the effect of Protestant missionaries appears to be positive. The missionary effect on English language proficiency appears to be largest for the countries that were not former UK or US colonies, in particular former French colonies with an almost 20 percentage point increase for the Protestant variable. A significantly smaller effect for immigrants from former UK/US colonies suggests that the effect we are finding is not derived from immigrants coming from former English-speaking colonies, but rather a missionary effect on their language proficiency.

(C) Analysis of Earnings

Among all men and women who worked last year, weekly earnings increased with level of schooling, proficiency in English, duration in the US, and living outside the southern states (full regressions including interaction terms are reported in Tables A-9 through A-14 of the Statistical Appendix, available upon request). Pre-immigration labor market experience (i.e., total experience when duration in the US is held constant) had a 
small positive effect on earnings for men, but generally a small negative effect for women. Married men earned substantially more than men not currently married (about 25.7 percent more for men from former UK or US colonies and 16.3 percent more for men not from former UK or US colonies). The marriage effect is positive but trivial (about 3 percent) for immigrant women who worked. For women the presence of children in the household has a negative effect on their earnings, about 4 percent, though this effect comes mostly from women that are coming from former Spanish colonies. Thus, women not currently married and without children in the household have higher weekly earnings than married women with children, other variables being the same.

The effect of schooling on earnings was fairly similar between both men and women. The effect is positive and largest for immigrants coming from former UK or US colonies, but the interaction term between Protestant missionaries and schooling for the immigrants from non-former UK or US colonies appears to minimize this difference at higher levels of schooling.

Table 3

Among all immigrants coming from a country with a higher concentration of Protestant missionaries, relative to Catholic missionaries, the effect on earnings is similar in magnitude (approximately 4 to 5 percent with a unit increase in missionaries per 10,000 population) though opposite in sign (Table 3). The positive effect on earnings associated with an increase in Protestant missionaries appears to be do to immigrants coming from countries that were not former UK/US colonies. The greatest Protestant missionary effect is for immigrants coming from former Spanish colonies. 
Moreover, the effect of weeks worked on annual earnings is greater than unity for all groups except the males from former Spanish colonies (full regressions reported in Tables A-9 through A-14 of the Statistical Appendix). Having a greater than unity weeks worked effect is consistent with most immigrants having a positive responsiveness in their work effort to higher wage rates. For males from former Spanish colonies, however, the log of weeks worked coefficient being less than unity indicates a greater seasonality in employment or greater measurement errors in weeks worked.

The earnings data have been adjusted for inflation and are in 2009 dollars. The dichotomous survey year variables (not shown here) indicate the difference in real weekly earnings (i.e., annual earnings controlling for weeks worked) from the benchmark survey 2009. The effects of the "Great Recession” are shown by the statistically significant decline in real weekly earnings in 2008 and 2009 compared to 2005 to 2007, by about 4 percent among all immigrants ${ }^{5}$.

Because of the large share of immigrants from Mexico in the sample, especially the former Spanish colonies sample, all of the equations were recomputed deleting Mexican immigrants from the data. With one exception this change has no material effect on any of the missionary variables. The one exception is the language proficiency analysis for the missionary variables for immigrants from the former Spanish colonies. Among both males and females, the significant negative Catholic coefficient becomes marginally significant and positive, and the Protestant coefficient changes from significant positive to significant

\footnotetext{
${ }^{5}$ With 2009 serving as the benchmark, the coefficients, with t-statistics in parenthesis, for the dichotomous year variables were 0.0715 (17.02), 0.0707 (17.68), 0.0825 (21.15), and 0.0421 (10.53) for the years 2005, 2006, 2007, and 2008, respectively.
} 
negative. The Mexican missionary variables are not outliers. It is not clear why these coefficients change signs.

Table 4

\section{Summary and Discussion}

This paper extends the findings of previous work on the impact of missionary activity within a less developed country by looking at people that have emigrated from that country. The findings are consistent with Protestant and Catholic missionaries having different impacts. Protestant missionaries, who tend to focus more on teaching their congregation to read the Bible compared to Catholic missionaries, have a large positive and statistically significant effect on the English proficiency and earnings of people that have immigrated to the US, while the Catholic missionary effect is highly significant but negative for language and earnings. These effects do not depend on whether the immigrant is coming from a former UK or US colony or not.

Thus, whether the form of human capital is formal schooling or English language proficiency, immigrants that came from a country with a higher density of Protestant missionaries have a greater return to their human capital investments compared to those from countries with a higher density of Catholic missionaries. In fact, we find that the magnitude of the Protestant-Catholic missionary difference for immigrants coming from countries that were not former UK or US colonies is significantly larger than those from former UK/US colonies. This suggests that the different missionary effect is not caused by the language of the former colonial ruler, but rather indicative of the type of missionary. 
This study demonstrates the importance of analyzing English language proficiency, earnings and other variables separately by missionary denomination. The "missionary variable” is too aggregate and may mask important findings because of strikingly different effects of Protestant and Catholic activities. While the previous literature focused on the impact of missionaries within the country, this paper suggests Protestant missionaries could be reducing the cost of migration to the US more so than Catholic missionaries. The lower cost of migration would lead to an increased flow of high-skilled workers out of the origin country. 


\section{References:}

(1) Barrett, David B. 1982. World Christian Encyclopedia: A Comparative Survey of Churches and Religions in the Modern World A.D. 1900-2000. New York: Oxford University Press.

(2) Berman, Eli. (1974). African Responses to Christian Mission Education. African Studies Review, 17 (3): 527-40.

(3) Chiswick, Barry R. 2000. Are Immigrants Favorable Self-Selected? An Economic Analysis. In Migration Theory: Talking Across Disciplines, eds. Caroline Brettell and James Hollifield, 61-76. New York: Routledge.

(4) Chiswick, Barry R. and Paul W. Miller. 2007. The Economics of Language: International Analyses, London: Routledge.

(5) Grier, R. 1997. The Effect of Religion on Economic Development: A CrossNational Study of 63 Former Colonies. Kyklos, 50(1), 47-62.

(6) Gordon-Conwell. 2013. Christianity in its Global Context, 1970-2020: Society, Religion, and Mission. Web. 08 April 2015. http://wwwgordonconwell.com/ netcommunity/CSGCResources/ChristianityinitsGlobalContext.pdf

(7) Mincer, Jacob. 1974. Schooling, Earnings and Experience, New York: National Bureau of Economic Research.

(8) Nunn, N. 2012. Gender and Missionary Influences in Colonial Africa. Book prepared for Africa’s Development Perspective. Department of Economics, Harvard University.

(9) Woodberry, Robert D. 2012. “The Missionary Roots of Liberal Democracy.” American Political Science Review 106(2): 244-274. 
(10) Woodberry, Robert D., Juan Carlos Esparza Ochoa, Reid Porter and Xiaoyun Lu. 2010. “Conceptual Framework and Technical Innovations for Creating the Project on Religion \& Economy Change Geo-Spatial Database.” Project on Religion and Economic Change Working Paper \#004.

(11) Woodberry, Robert D. 2007. “Economics” pp. 123-7 Encyclopedia of Missions and Missionaries. Jonathan Bonk (ed.). New York: Routledge.

(12) Woodberry, Robert D. 2004. "The Shadow of Empire: Christian Missions, Colonial Policy, and Democracy in Post-colonial Societies.” Ph.D. diss. University of North Carolina-Chapel Hill. 
Table 1. Largest Christian missionary sending countries: 2010 and 1980

\begin{tabular}{lcr} 
Country & $2010^{\mathrm{a}}$ & $1980^{\mathrm{b}}$ \\
\hline English Language Countries & & \\
\hline U.S. & 127,000 & 57,212 \\
United Kingdom & 15,000 & 10,288 \\
Canada & 8,500 & 10,173 \\
\hline \multicolumn{2}{l}{ Non-English Language Countries } & \\
\hline Brazil & 34,000 & 2,456 \\
Spain & 21,000 & 27,901 \\
Italy & 20,000 & 25,321 \\
S. Korea & 20,000 & 620 \\
Germany & 14,000 & 16,857 \\
India & 10,000 & 3,931
\end{tabular}

Source: a. Gordon-Conwell's Center for the Study of Global Christianity, Christianity in its Global Context, June 2013, page 76.

b. Barrett, David B. 1982. World Christian Encyclopedia: A Comparative Survey of Churches and Religions in the Modern World A.D. 1900-2000 Global Table 31 pages 802-803. 
Table 2: Analysis of the Effect of Missionary Concentration on English Language Proficiency Among Adult Males and Females by Origin Country Colonial Heritage

\begin{tabular}{lccccc}
\hline & $(1)$ & $(2)$ & $(3)$ & $(4)$ & $(5)$ \\
Males: & All & UK/US & Not UK/US & French & Spain \\
\hline Catholic & & & & & \\
& $-0.0394^{* * *}$ & $-0.0100^{* * *}$ & $-0.0232^{* * *}$ & $-0.1560^{* * *}$ & $-0.0081^{* * *}$ \\
Protestant & $(0.0009)$ & $(0.0012)$ & $(0.0010)$ & $(0.0087)$ & $(0.0017)$ \\
& $0.0949^{* * *}$ & $0.0293^{* * *}$ & $0.0704^{* * *}$ & $0.1968^{* * *}$ & $0.0805^{* * *}$ \\
& $(0.0010)$ & $(0.0013)$ & $(0.0021)$ & $(0.0079)$ & $(0.0068)$ \\
Females: & & & & & \\
Catholic & & & & & \\
& & & & & \\
Protestant & $-0.0327^{* * *}$ & $-0.0092^{* * *}$ & $-0.0266^{* * *}$ & $-0.1330^{* * *}$ & $-0.0261^{* * *}$ \\
& $(0.0009)$ & $(0.0010)$ & $(0.0011)$ & $(0.0106)$ & $(0.0017)$ \\
& $0.0934^{* * *}$ & $0.0301^{* * *}$ & $0.0729^{* * *}$ & $0.2082^{* * *}$ & $0.0695^{* * *}$ \\
& $(0.0010)$ & $(0.0012)$ & $(0.0023)$ & $(0.0094)$ & $(0.0064)$
\end{tabular}

Robust standard errors in parentheses

$* * * \mathrm{p}<0.001, * * \mathrm{p}<0.01, * \mathrm{p}<0.05$

Notes: Variables held constant include: marital status, children, age at migration, schooling, years since migration, years since migration squared, and year fix effects. Foreign-born males and females age 25 to 64 years who worked in the previous year.

Source: U.S. Bureau of the Census, American Community Survey, PUMS, 2005-09 
Table 3: Analysis of the Effect of Missionary Concentration on Earnings Among Adult Males and Females by Origin Country Colonial Heritage

\begin{tabular}{lccccc}
\hline & $(1)$ & $(2)$ & $(3)$ & $(4)$ & $(5)$ \\
Males: & All & UK/US & Not UK/US & French & Spain \\
\hline Catholic & $-0.0520^{* * *}$ & $-0.0075^{* *}$ & $-0.0526^{* * *}$ & 0.0359 & $0.0080^{* *}$ \\
& $(0.0014)$ & $(0.0024)$ & $(0.0018)$ & $(0.0187)$ & $(0.0026)$ \\
Protestant & $0.0434^{* * *}$ & -0.0078 & $0.1050^{* * *}$ & $0.1060^{* * *}$ & $0.1857^{* * *}$ \\
& $(0.0027)$ & $(0.0042)$ & $(0.0059)$ & $(0.0189)$ & $(0.0127)$ \\
& & & & \\
Females: & & & & & \\
Catholic & & & & & \\
& & & & & \\
Protestant & $\left(0.0500^{* * *}\right.$ & $-0.0108^{* * *}$ & $-0.0678^{* * *}$ & 0.0355 & $-0.0528 * * *$ \\
& $0.0456^{* * *}$ & $(0.0020)$ & $(0.0020)$ & $(0.0214)$ & $(0.0029)$ \\
& $(0.0025)$ & $(0.0037)$ & $(0.0065)$ & $(0.0235)$ & $(0.0130)$
\end{tabular}

Robust standard errors in parentheses

*** $\mathrm{p}<0.001, * * \mathrm{p}<0.01, * \mathrm{p}<0.05$

Notes: Variables held constant include: English language proficiency, experience, experience squared, weeks worked, marital status, children, living in a southern state, schooling, years since migration, years since migration squared, and year fix effects. Foreign-born males and females age 25 to 64 years who worked in the previous year.

Source: U.S. Bureau of the Census, American Community Survey, PUMS, 2005-09 
Table 4: Partial Effects of the Missionary Variables on English Language Proficiencies, Other Variables the Same, When Mexican Immigrants are Included and Excluded From the Former Spanish Colonies Sample

(1) (2)

\begin{tabular}{lcc} 
Male: & Included & Excluded \\
\hline & & \\
Catholic & $-0.0081^{* * *}$ & $0.0039^{*}$ \\
& $(0.0017)$ & $(0.0017)$ \\
Protestant & $0.0805^{* * *}$ & $-0.0843^{* * *}$ \\
& $(0.0068)$ & $(0.0074)$ \\
& & \\
Female: & & \\
\hline & & \\
Catholic & $-0.0261^{* * *}$ & $-0.0101^{* * *}$ \\
& $(0.0017)$ & $(0.0017)$ \\
Protestant & $0.0695^{* * *}$ & $-0.0430^{* * *}$ \\
& $(0.0064)$ & $(0.0069)$
\end{tabular}

Robust standard errors in parentheses

*** $\mathrm{p}<0.001,{ }^{* *} \mathrm{p}<0.01,{ }^{*} \mathrm{p}<0.05$

Notes: Variables held constant include: marital status, children, age at migration, schooling, years since migration, years since migration squared, and year fix effects. Foreign-born males and females age 25 to 64 years who worked in the previous year. Data limited to immigrants from the former Spanish colonies.

Source: U.S. Bureau of the Census, American Community Survey, PUMS, 2005-09 


\section{Statistical Appendix:}

Table A-1: Descriptive Statistics of the Variables for Foreign-Born Males and Females, American Community Survey, 2005-09

\author{
Foreign-Born Males \\ Variable \\ Total Earnings \\ Adjusted Total Earnings \\ Ln Adjusted Total Earnings \\ Schooling \\ Good English \\ Experience \\ Experience Squared \\ Years Since Migration (YSM) \\ YSM Squared \\ Married/Cohabitating \\ South \\ Ln Weeks Worked \\ Kids \\ Catholic \\ Catholic*Schooling \\ Catholic*YSM \\ Protestant \\ Protestant*Schooling \\ Protestant*YSM \\ Total Missionary \\ Total*Schooling \\ Total*YSM
}

$\begin{array}{rrr}\text { Obs } & \text { Mean } & \text { Std. Dev } \\ 415061 & 44335.22 & 52516.54 \\ 415061 & 46535.28 & 55030.46 \\ 415061 & 10.34392 & 0.9209196 \\ 415061 & 12.25931 & 4.518795 \\ 415061 & 0.700579 & 0.458005 \\ 415061 & 24.22061 & 10.98822 \\ 415061 & 707.3787 & 591.3628 \\ 415061 & 18.38482 & 11.3676 \\ 415061 & 467.2237 & 515.1632 \\ 415061 & 0.6476807 & 0.4776934 \\ 415061 & 0.335676 & 0.4722268 \\ 415061 & 3.793564 & 0.3952475 \\ 415061 & 0 & 0 \\ 415061 & 1.339837 & 1.079221 \\ 415061 & 14.90832 & 14.59766 \\ 415061 & 24.97126 & 28.67508 \\ 415061 & 0.3479115 & 0.5530391 \\ 415061 & 4.512261 & 8.025154 \\ 415061 & 6.694151 & 14.0925 \\ 415061 & 1.687749 & 1.294009 \\ 415061 & 19.42058 & 18.43126 \\ 415061 & 31.66541 & 36.44122\end{array}$

$\begin{array}{rr}\text { Min } & \text { Max } \\ 1000 & 974000 \\ 999.48 & 988146.4 \\ 6.907235 & 13.80359 \\ 0 & 20 \\ 0 & 1 \\ 0 & 59 \\ 0 & 3481 \\ 0 & 65 \\ 0 & 4225 \\ 0 & 1 \\ 0 & 1 \\ 1.94591 & 3.931826 \\ 0 & 0 \\ 0 & 15.38088 \\ 0 & 307.6176 \\ 0 & 884.185 \\ 0 & 9.05131 \\ 0 & 181.0262 \\ 0 & 579.2838 \\ 0 & 22.8667 \\ 0 & 457.334 \\ 0 & 1463.469\end{array}$

$\begin{array}{lrrrrr}\begin{array}{l}\text { Foreign-Born Females } \\ \text { Variable }\end{array} & \text { Obs } & \text { Mean } & \text { Std. Dev } & \text { Min } & \text { Max } \\ \text { Total Earnings } & 325280 & 31086.43 & 35091.23 & 1000 & 822000 \\ \text { Adjusted Total Earnings } & 325280 & 32594.98 & 36668.03 & 999.48 & 821572.6 \\ \text { Ln Adjusted Total Earnings } & 325280 & 9.932762 & 1.042046 & 6.907235 & 13.61898 \\ \text { Schooling } & 325280 & 12.80985 & 4.138288 & 0 & 20 \\ \text { Good English } & 325280 & 0.7264511 & 0.4457808 & 0 & 1 \\ \text { Experience } & 325280 & 24.43969 & 11.15665 & 0 & 59 \\ \text { Experience Squared } & 325280 & 721.7689 & 592.7247 & 0 & 3481 \\ \text { Years Since Migration (YSM) } & 325280 & 19.16359 & 11.47238 & 0 & 65 \\ \text { YSM Squared } & 325280 & 498.8582 & 536.4626 & 0 & 4225\end{array}$




$\begin{array}{lrrrrr}\text { Married/Cohabitating } & 325280 & 0.6137328 & 0.4868938 & 0 & 1 \\ \text { South } & 325280 & 0.3217013 & 0.4671298 & 0 & 1 \\ \text { Ln Weeks Worked } & 325280 & 3.698443 & 0.5244647 & 1.94591 & 3.931826 \\ \text { Kids } & 325280 & 0.4897442 & 0.4998956 & 0 & 1 \\ \text { Catholic } & 325280 & 1.275582 & 1.173928 & 0 & 15.38088 \\ \text { Catholic*Schooling } & 325280 & 15.35709 & 16.32094 & 0 & 307.6176 \\ \text { Catholic*YSM } & 325280 & 25.00154 & 31.12215 & 0 & 801.2927 \\ \text { Protestant } & 325280 & 0.3927257 & 0.6386418 & 0 & 9.05131 \\ \text { Protestant*Schooling } & 325280 & 5.26526 & 9.193091 & 0 & 181.0262 \\ \text { Protestant*YSM } & 325280 & 7.890107 & 16.34722 & 0 & 524.976 \\ \text { Total Missionary } & 325280 & 1.668308 & 1.446585 & 0 & 22.8667 \\ \text { Total*Schooling } & 325280 & 20.62235 & 20.82359 & 0 & 457.334 \\ \text { Total*YSM } & 325280 & 32.89164 & 40.38652 & 0 & 1326.269\end{array}$

Note: Foreign-born males and females age 25 to 64 years who worked in the previous year. Adjusted Total Earnings means earnings adjusted for price differences in each year, expressed in 2009 dollars.

Source: American Community Survey, PUMS, 2005-09 
Table A-2: Countries by Primary Colonial Heritage ${ }^{(1)}$

\begin{tabular}{|c|c|c|c|c|c|c|}
\hline \multicolumn{2}{|c|}{ UK/US } & French & Spanish & \multicolumn{2}{|l|}{ None } & Other \\
\hline $\begin{array}{l}\text { Antigua and } \\
\text { Barbuda }\end{array}$ & Myanmar & Algeria & Argentina & Afghanistan & American Samoa & Kazakhstan \\
\hline Bahamas & Nigeria & Cambodia & Bolivia & Bhutan & Angola & North Korea \\
\hline Bahrain & Pakistan & Cameroon & Chile & China & Armenia & South Korea \\
\hline Bangladesh & Qatar & Laos & Colombia & Ethiopia & Azerbaijan & Kyrgyzstan \\
\hline Barbados & Seychelles & Lebanon & Costa Rica & Iran & Benin & Libya \\
\hline Belize & Sierra Leone & Morocco & Cuba & Japan & Brazil & Madagascar \\
\hline Botswana & Singapore & Senegal & $\begin{array}{l}\text { Dominican } \\
\text { Republic }\end{array}$ & Liberia & Burkina Faso & Mali \\
\hline Brunei & Solomon Islands & Syria & Ecuador & Nepal & Burundi & Mauritania \\
\hline Cyprus & Somalia & Vietnam & El Salvador & Saudi Arabia & Cape Verde & Mongolia \\
\hline Dominica & South Africa & & Guatemala & Thailand & Central African Republic & Mozambique \\
\hline Egypt & Sri Lanka & & Guinea & Turkey & Chad & Namibia \\
\hline Fiji & St. Kitts & & Haiti & Yemen & Comoros & Nauru \\
\hline Gambia & St. Lucia & & Honduras & & $\begin{array}{l}\text { Congo (Democratic } \\
\text { Republic) }\end{array}$ & Niger \\
\hline Ghana & St. Vincent & & Mexico & & Congo (Republic of the) & Oman \\
\hline Grenada & Sudan & & Nicaragua & & Cote d'Ivoire & Palau \\
\hline Guyana & Swaziland & & Panama & & Djibouti & Papua New Guinea \\
\hline India & Tanzania & & Paraguay & & Equatorial Guinea & Rwanda \\
\hline Jamaica & Tonga & & Peru & & Eritrea & Samoa \\
\hline Kenya & $\begin{array}{l}\text { Trinidad and } \\
\text { Tobago }\end{array}$ & & Philippines & & Micronesia & Sao Tome and Principe \\
\hline Kiribati & Tuvalu & & Uruguay & & Gabon & Suriname \\
\hline Kuwait & $\begin{array}{l}\text { Uganda } \\
\text { United Arab }\end{array}$ & & Venezuela & & Guinea-Bissau & Tajikistan \\
\hline Lesotho & Emirates & & & & Indonesia & Togo \\
\hline Malawi & Vanuatu & & & & Iraq & Tunisia \\
\hline Malaysia & Zambia & & & & Israel & Turkmenistan \\
\hline Maldives & Zimbabwe & & & & Jordan & Uzbekistan \\
\hline Mauritius & & & & & & \\
\hline
\end{tabular}

Source:

Woodberry, Robert D. 2004. "The Shadow of Empire: Christian Missions, Colonial Policy, and Democracy in Post-colonial Societies." Ph.D. diss. University of North Carolina-Chapel Hill. Page 57.

(1) Does not include Europe, Canada, Australia, and New Zealand. 
Table A-3: Analysis of English Language Proficiency Among Foreign-Born Adult Males by Origin Country

Colonial Heritage

American Community Survey, 2005-09

(Dependent Variable: GoodEnglish)

\begin{tabular}{|c|c|c|c|c|c|}
\hline & (1) & (2) & (3) & (4) & (5) \\
\hline VARIABLES & All & UK/US & Non UK/US & French & Spanish \\
\hline Married Spouse Present & $\begin{array}{c}0.0534 * * * \\
(0.0017)\end{array}$ & $\begin{array}{c}0.0017 \\
(0.0025)\end{array}$ & $\begin{array}{c}0.0558 * * * \\
(0.0019)\end{array}$ & $\begin{array}{c}0.0011 \\
(0.0060)\end{array}$ & $\begin{array}{c}0.0659 * * * \\
(0.0022)\end{array}$ \\
\hline Age at Migration & $\begin{array}{c}-0.0068 * * * \\
(0.0001)\end{array}$ & $\begin{array}{c}-0.0025^{* * *} \\
(0.0001)\end{array}$ & $\begin{array}{c}-0.0076^{* * *} \\
(0.0001)\end{array}$ & $\begin{array}{c}-0.0104^{* * *} \\
(0.0003)\end{array}$ & $\begin{array}{c}-0.0068^{* * * *} \\
(0.0001)\end{array}$ \\
\hline Schooling & $\begin{array}{c}0.0471^{* * *} \\
(0.0004)\end{array}$ & $\begin{array}{c}0.0202 * * * \\
(0.0007)\end{array}$ & $\begin{array}{c}0.0448 * * * \\
(0.0005)\end{array}$ & $\begin{array}{c}0.0286 * * * \\
(0.0016)\end{array}$ & $\begin{array}{c}0.0453 * * * \\
(0.0011)\end{array}$ \\
\hline Years Since Migration & $\begin{array}{c}0.0189 * * * \\
(0.0002)\end{array}$ & $\begin{array}{c}0.0060 * * * \\
(0.0004)\end{array}$ & $\begin{array}{c}0.0223^{* * *} \\
(0.0003)\end{array}$ & $\begin{array}{c}0.0133^{* * *} \\
(0.0011)\end{array}$ & $\begin{array}{c}0.0269 * * * \\
(0.0004)\end{array}$ \\
\hline YSM Squared & $\begin{array}{c}-0.0002^{* * *} \\
(0.0000)\end{array}$ & $\begin{array}{c}-0.0001^{* * *} \\
(0.0000)\end{array}$ & $\begin{array}{c}-0.0002 * * * \\
(0.0000)\end{array}$ & $\begin{array}{c}-0.0002 * * * \\
(0.0000)\end{array}$ & $\begin{array}{c}-0.0003^{* * * *} \\
(0.0000)\end{array}$ \\
\hline Catholic Missionary & $\begin{array}{c}-0.0904^{* * *} \\
(0.0038)\end{array}$ & $\begin{array}{c}-0.0407^{* * *} \\
(0.0060)\end{array}$ & $\begin{array}{c}-0.0583 * * * \\
(0.0040)\end{array}$ & $\begin{array}{c}-0.5040 * * * \\
(0.0429)\end{array}$ & $\begin{array}{l}-0.0058 \\
(0.0061)\end{array}$ \\
\hline Catholic*Schooling & $\begin{array}{l}0.0005^{*} \\
(0.0002)\end{array}$ & $\begin{array}{c}0.0022^{* * *} \\
(0.0004)\end{array}$ & $\begin{array}{c}0.0002 \\
(0.0003)\end{array}$ & $\begin{array}{c}0.0116 * * * \\
(0.0025)\end{array}$ & $\begin{array}{l}-0.0001 \\
(0.0005)\end{array}$ \\
\hline Catholic*YSM & $\begin{array}{c}0.0026 * * * \\
(0.0001)\end{array}$ & $\begin{array}{l}0.0002 * \\
(0.0001)\end{array}$ & $\begin{array}{c}0.0019 * * * \\
(0.0001)\end{array}$ & $\begin{array}{c}0.0101^{* * *} \\
(0.0009)\end{array}$ & $\begin{array}{l}-0.0000 \\
(0.0001)\end{array}$ \\
\hline Protestant Missionary & $\begin{array}{c}0.3731^{* * *} \\
(0.0073)\end{array}$ & $\begin{array}{c}0.1493 * * * \\
(0.0096)\end{array}$ & $\begin{array}{c}0.2036^{* * * *} \\
(0.0118)\end{array}$ & $\begin{array}{c}0.6527 * * * \\
(0.0448)\end{array}$ & $\begin{array}{c}0.1863 * * * \\
(0.0289)\end{array}$ \\
\hline Protestant*Schooling & $\begin{array}{c}-0.0144^{* * *} \\
(0.0005)\end{array}$ & $\begin{array}{c}-0.0076^{* * *} \\
(0.0006)\end{array}$ & $\begin{array}{c}-0.0048 * * * \\
(0.0007)\end{array}$ & $\begin{array}{c}-0.0178 * * * \\
(0.0026)\end{array}$ & $\begin{array}{c}-0.0067 * * \\
(0.0021)\end{array}$ \\
\hline Protestant*YSM & $\begin{array}{c}-0.0044 * * * \\
(0.0001)\end{array}$ & $\begin{array}{c}-0.0008 * * * \\
(0.0001)\end{array}$ & $\begin{array}{c}-0.0034^{* * *} \\
(0.0002)\end{array}$ & $\begin{array}{c}-0.0105^{* * *} \\
(0.0008)\end{array}$ & $\begin{array}{l}-0.0010^{*} \\
(0.0005)\end{array}$ \\
\hline Constant & $\begin{array}{c}0.1266 * * * \\
(0.0080)\end{array}$ & $\begin{array}{c}0.6688 * * * \\
(0.0131)\end{array}$ & $\begin{array}{c}0.1125^{* * * *} \\
(0.0088)\end{array}$ & $\begin{array}{c}0.7259 * * * \\
(0.0323)\end{array}$ & $\begin{array}{l}-0.0331^{*} \\
(0.0155)\end{array}$ \\
\hline Observations & 415,061 & 64,052 & 351,009 & 26,343 & 263,437 \\
\hline R-squared & 0.3145 & 0.1112 & 0.2882 & 0.2922 & 0.2632 \\
\hline Adj R-sq & 0.314 & 0.111 & 0.288 & 0.292 & 0.263 \\
\hline Mean & 0.665 & 0.960 & 0.615 & 0.778 & 0.564 \\
\hline Standard Deviation & 0.472 & 0.195 & 0.487 & 0.415 & 0.496 \\
\hline
\end{tabular}

Robust standard errors in parentheses

$* * * \mathrm{p}<0.001, * * \mathrm{p}<0.01, * \mathrm{p}<0.05$

Year fixed effects variables included in the equation, but not shown in Table.

Notes: Foreign-born persons age 25 to 64 years who worked in the prior year.

Source: U.S. Bureau of the Census, American Community Survey, PUMS, 2005-09 
Table A-4: Analysis of English Language Proficiency Among Foreign-Born Adult Females by Origin Country

Colonial Heritage

American Community Survey, 2005-09

(Dependent Variable: GoodEnglish)

\begin{tabular}{|c|c|c|c|c|c|}
\hline VARIABLES & $\begin{array}{l}(1) \\
\text { All }\end{array}$ & $\begin{array}{c}(2) \\
\text { UK/US }\end{array}$ & $\begin{array}{c}(3) \\
\text { Non UK/US }\end{array}$ & $\begin{array}{c}(4) \\
\text { French }\end{array}$ & $\begin{array}{c}\text { (5) } \\
\text { Spanish }\end{array}$ \\
\hline Married Spouse Present & $\begin{array}{c}0.0234 * * * \\
(0.0018)\end{array}$ & $\begin{array}{c}-0.0227 * * * \\
(0.0023)\end{array}$ & $\begin{array}{c}0.0290^{* * * *} \\
(0.0020)\end{array}$ & $\begin{array}{l}-0.0106 \\
(0.0073)\end{array}$ & $\begin{array}{c}0.0353 * * * \\
(0.0024)\end{array}$ \\
\hline Age at Migration & $\begin{array}{c}-0.0066^{* * *} \\
(0.0001)\end{array}$ & $\begin{array}{c}-0.0019 * * * \\
(0.0001)\end{array}$ & $\begin{array}{c}-0.0077 * * * \\
(0.0001)\end{array}$ & $\begin{array}{c}-0.0105^{* * *} \\
(0.0004)\end{array}$ & $\begin{array}{c}-0.0068 * * * \\
(0.0001)\end{array}$ \\
\hline Schooling & $\begin{array}{c}0.0505 * * * \\
(0.0005)\end{array}$ & $\begin{array}{c}0.0261 * * * \\
(0.0009)\end{array}$ & $\begin{array}{c}0.0480 * * * \\
(0.0005)\end{array}$ & $\begin{array}{c}0.0384 * * * \\
(0.0016)\end{array}$ & $\begin{array}{c}0.0628 * * * \\
(0.0011)\end{array}$ \\
\hline Years Since Migration & $\begin{array}{c}0.0168 * * * \\
(0.0002)\end{array}$ & $\begin{array}{c}0.0071^{* * *} \\
(0.0004)\end{array}$ & $\begin{array}{c}0.0187 * * * \\
(0.0003)\end{array}$ & $\begin{array}{c}0.0154 * * * \\
(0.0013)\end{array}$ & $\begin{array}{c}0.0206 * * * \\
(0.0004)\end{array}$ \\
\hline YSM Squared & $\begin{array}{c}-0.0001^{* * *} \\
(0.0000)\end{array}$ & $\begin{array}{c}-0.0001^{* * *} \\
(0.0000)\end{array}$ & $\begin{array}{c}-0.0002^{* * *} \\
(0.0000)\end{array}$ & $\begin{array}{c}-0.0001^{* * *} \\
(0.0000)\end{array}$ & $\begin{array}{c}-0.0002^{* * *} \\
(0.0000)\end{array}$ \\
\hline Kids & $\begin{array}{c}-0.0207 * * * \\
(0.0018)\end{array}$ & $\begin{array}{c}0.0006 \\
(0.0023)\end{array}$ & $\begin{array}{c}-0.0264 * * * \\
(0.0021)\end{array}$ & $\begin{array}{c}-0.0186 * * \\
(0.0071)\end{array}$ & $\begin{array}{c}-0.0302 * * * \\
(0.0025)\end{array}$ \\
\hline Catholic Missionary & $\begin{array}{c}-0.1179 * * * \\
(0.0051)\end{array}$ & $\begin{array}{c}-0.0418 * * * \\
(0.0066)\end{array}$ & $\begin{array}{c}-0.1108 * * * \\
(0.0044)\end{array}$ & $\begin{array}{c}-0.3221 * * * \\
(0.0407)\end{array}$ & $\begin{array}{l}-0.0073 \\
(0.0071)\end{array}$ \\
\hline Catholic*Schooling & $\begin{array}{c}0.0042 * * * \\
(0.0003)\end{array}$ & $\begin{array}{c}0.0023 * * * \\
(0.0004)\end{array}$ & $\begin{array}{c}0.0041^{* * *} \\
(0.0003)\end{array}$ & $\begin{array}{c}0.0014 \\
(0.0025)\end{array}$ & $\begin{array}{c}-0.0027^{* * *} \\
(0.0005)\end{array}$ \\
\hline Catholic*YSM & $\begin{array}{c}0.0017 * * * \\
(0.0001)\end{array}$ & $\begin{array}{c}0.0001 \\
(0.0001)\end{array}$ & $\begin{array}{c}0.0016 * * * \\
(0.0001)\end{array}$ & $\begin{array}{c}0.0094^{* * *} \\
(0.0010)\end{array}$ & $\begin{array}{c}0.0010^{* * * *} \\
(0.0001)\end{array}$ \\
\hline Protestant Missionary & $\begin{array}{c}0.4465 * * * \\
(0.0074)\end{array}$ & $\begin{array}{c}0.1953 * * * \\
(0.0098)\end{array}$ & $\begin{array}{c}0.2868 * * * \\
(0.0143)\end{array}$ & $\begin{array}{c}0.6145^{* * *} \\
(0.0492)\end{array}$ & $\begin{array}{c}0.2922 * * * \\
(0.0319)\end{array}$ \\
\hline Protestant*Schooling & $\begin{array}{c}-0.0199 * * * \\
(0.0005)\end{array}$ & $\begin{array}{c}-0.0102 * * * \\
(0.0006)\end{array}$ & $\begin{array}{c}-0.0105^{* * *} \\
(0.0009)\end{array}$ & $\begin{array}{c}-0.0124^{* * *} \\
(0.0030)\end{array}$ & $\begin{array}{c}-0.0136 * * * \\
(0.0022)\end{array}$ \\
\hline Protestant*YSM & $\begin{array}{c}-0.0042^{* * *} \\
(0.0001)\end{array}$ & $\begin{array}{c}-0.0012 * * * \\
(0.0001)\end{array}$ & $\begin{array}{c}-0.0034^{* * *} \\
(0.0002)\end{array}$ & $\begin{array}{c}-0.0120 * * * \\
(0.0009)\end{array}$ & $\begin{array}{c}-0.0019 * * * \\
(0.0005)\end{array}$ \\
\hline Constant & $\begin{array}{c}0.1001^{* * *} \\
(0.0096)\end{array}$ & $\begin{array}{c}0.5445^{* * *} \\
(0.0167)\end{array}$ & $\begin{array}{c}0.1351^{* * *} \\
(0.0098)\end{array}$ & $\begin{array}{c}0.4860 * * * \\
(0.0353)\end{array}$ & $\begin{array}{c}-0.1180^{* * * *} \\
(0.0179)\end{array}$ \\
\hline Observations & 325,280 & 50,634 & 274,646 & 22,713 & 194,598 \\
\hline R-squared & 0.3467 & 0.1490 & 0.3310 & 0.3462 & 0.3260 \\
\hline Adj R-sq & 0.347 & 0.149 & 0.331 & 0.346 & 0.326 \\
\hline Mean & 0.703 & 0.956 & 0.657 & 0.690 & 0.614 \\
\hline Standard Deviation & 0.457 & 0.204 & 0.475 & 0.463 & 0.487 \\
\hline
\end{tabular}

Robust standard errors in parentheses

*** $\mathrm{p}<0.001, * * \mathrm{p}<0.01, * \mathrm{p}<0.05$

Year fixed effects variables included in the equation, but not shown in Table.

Notes: Foreign-born persons age 25 to 64 years who worked in the prior year.

Source: U.S. Bureau of the Census, American Community Survey, PUMS, 2005-09 
Table A-5: Analysis of English Language Proficiency Among Foreign-Born Adult Males by Origin Country Colonial Heritage: Catholic Missionary Only

American Community Survey, 2005-09

(Dependent Variable: GoodEnglish)

\begin{tabular}{|c|c|c|c|c|c|}
\hline VARIABLES & $\begin{array}{l}(1) \\
\text { All }\end{array}$ & $\begin{array}{c}(2) \\
\text { UK/US }\end{array}$ & $\begin{array}{c}(3) \\
\text { Non UK/US }\end{array}$ & $\begin{array}{c}\text { (4) } \\
\text { French }\end{array}$ & $\begin{array}{c}(5) \\
\text { Spanish }\end{array}$ \\
\hline Married Spouse Present & $\begin{array}{c}0.0528 * * * \\
(0.0017)\end{array}$ & $\begin{array}{l}-0.0004 \\
(0.0025)\end{array}$ & $\begin{array}{c}0.0561^{* * * *} \\
(0.0019)\end{array}$ & $\begin{array}{c}0.0069 \\
(0.0061)\end{array}$ & $\begin{array}{c}0.0652 * * * \\
(0.0022)\end{array}$ \\
\hline Age at Migration & $\begin{array}{c}-0.0064 * * * \\
(0.0001)\end{array}$ & $\begin{array}{c}-0.0025^{* * *} \\
(0.0001)\end{array}$ & $\begin{array}{c}-0.0076^{* * * *} \\
(0.0001)\end{array}$ & $\begin{array}{c}-0.0108 * * * \\
(0.0003)\end{array}$ & $\begin{array}{c}-0.0067 * * * \\
(0.0001)\end{array}$ \\
\hline Schooling & $\begin{array}{c}0.0436 * * * \\
(0.0004)\end{array}$ & $\begin{array}{c}0.0127^{* * * *} \\
(0.0005)\end{array}$ & $\begin{array}{c}0.0438^{* * * *} \\
(0.0004)\end{array}$ & $\begin{array}{c}0.0323 * * * \\
(0.0013)\end{array}$ & $\begin{array}{c}0.0426 * * * \\
(0.0009)\end{array}$ \\
\hline Years Since Migration & $\begin{array}{c}0.0181^{* * *} \\
(0.0002)\end{array}$ & $\begin{array}{c}0.0063^{* * * *} \\
(0.0004)\end{array}$ & $\begin{array}{c}0.0215^{* * *} \\
(0.0003)\end{array}$ & $\begin{array}{c}0.0161^{* * *} \\
(0.0011)\end{array}$ & $\begin{array}{c}0.0264 * * * \\
(0.0004)\end{array}$ \\
\hline YSM Squared & $\begin{array}{c}-0.0002 * * * \\
(0.0000)\end{array}$ & $\begin{array}{c}-0.0001^{* * *} \\
(0.0000)\end{array}$ & $\begin{array}{c}-0.0002^{* * *} \\
(0.0000)\end{array}$ & $\begin{array}{c}-0.0001^{* * *} \\
(0.0000)\end{array}$ & $\begin{array}{c}-0.0003^{* * *} \\
(0.0000)\end{array}$ \\
\hline Catholic Missionary & $\begin{array}{c}-0.0930 * * * \\
(0.0041)\end{array}$ & $\begin{array}{c}-0.0188^{* *} \\
(0.0059)\end{array}$ & $\begin{array}{c}-0.0581^{* * *} \\
(0.0040)\end{array}$ & $\begin{array}{c}-0.0815^{* *} \\
(0.0263)\end{array}$ & $\begin{array}{c}-0.0201^{* * *} \\
(0.0059)\end{array}$ \\
\hline Catholic*Schooling & $\begin{array}{c}0.0014 * * * \\
(0.0002)\end{array}$ & $\begin{array}{c}0.0013^{* * *} \\
(0.0004)\end{array}$ & $\begin{array}{c}0.0005 \\
(0.0003)\end{array}$ & $\begin{array}{c}0.0048 * * \\
(0.0015)\end{array}$ & $\begin{array}{c}0.0007 \\
(0.0005)\end{array}$ \\
\hline Catholic*YSM & $\begin{array}{c}0.0025^{* * *} \\
(0.0001)\end{array}$ & $\begin{array}{c}0.0000 \\
(0.0001)\end{array}$ & $\begin{array}{c}0.0018^{* * * *} \\
(0.0001)\end{array}$ & $\begin{array}{l}0.0009 * \\
(0.0004)\end{array}$ & $\begin{array}{c}0.0001 \\
(0.0001)\end{array}$ \\
\hline Constant & $\begin{array}{c}0.2074 * * * \\
(0.0081)\end{array}$ & $\begin{array}{c}0.8016 * * * \\
(0.0101)\end{array}$ & $\begin{array}{c}0.1533^{* * * *} \\
(0.0084)\end{array}$ & $\begin{array}{c}0.5475 * * * \\
(0.0289)\end{array}$ & $\begin{array}{c}0.0326 * * \\
(0.0123)\end{array}$ \\
\hline Observations & 415,061 & 64,052 & 351,009 & 26,343 & 263,437 \\
\hline R-squared & 0.2990 & 0.0780 & 0.2862 & 0.2627 & 0.2627 \\
\hline Adj R-sq & 0.299 & 0.0778 & 0.286 & 0.262 & 0.263 \\
\hline Mean & 0.665 & 0.960 & 0.615 & 0.778 & 0.564 \\
\hline Standard Deviation & 0.472 & 0.195 & 0.487 & 0.415 & 0.496 \\
\hline
\end{tabular}

Robust standard errors in parentheses

$* * * \mathrm{p}<0.001, * * \mathrm{p}<0.01, * \mathrm{p}<0.05$

Year fixed effects variables included in the equation, but not shown in Table.

Notes: Foreign-born persons age 25 to 64 years who worked in the prior year.

Source: U.S. Bureau of the Census, American Community Survey, PUMS, 2005-09 
Table A-6: Analysis of English Language Proficiency Among Foreign-Born Adult Females by Origin Country Colonial Heritage: Catholic Missionary Only

American Community Survey, 2005-09

(Dependent Variable: GoodEnglish)

\begin{tabular}{|c|c|c|c|c|c|}
\hline & (1) & (2) & (3) & (4) & (5) \\
\hline VARIABLES & All & UK/US & Non UK/US & French & Spanish \\
\hline Married Spouse Present & $\begin{array}{c}0.0164 * * * \\
(0.0018)\end{array}$ & $\begin{array}{c}-0.0303 * * * \\
(0.0024)\end{array}$ & $\begin{array}{c}0.0283^{* * *} \\
(0.0020)\end{array}$ & $\begin{array}{l}-0.0116 \\
(0.0075)\end{array}$ & $\begin{array}{c}0.0344 * * * \\
(0.0024)\end{array}$ \\
\hline Age at Migration & $\begin{array}{c}-0.0061 * * * \\
(0.0001)\end{array}$ & $\begin{array}{c}-0.0017 * * * \\
(0.0001)\end{array}$ & $\begin{array}{c}-0.0076 * * * \\
(0.0001)\end{array}$ & $\begin{array}{c}-0.0108 * * * \\
(0.0004)\end{array}$ & $\begin{array}{c}-0.0068^{* * *} \\
(0.0001)\end{array}$ \\
\hline Schooling & $\begin{array}{c}0.0461^{* * *} \\
(0.0005)\end{array}$ & $\begin{array}{c}0.0155^{* * *} \\
(0.0007)\end{array}$ & $\begin{array}{c}0.0462 * * * \\
(0.0005)\end{array}$ & $\begin{array}{c}0.0356^{* * *} \\
(0.0015)\end{array}$ & $\begin{array}{c}0.0579 * * * \\
(0.0009)\end{array}$ \\
\hline Years Since Migration & $\begin{array}{c}0.0159 * * * \\
(0.0002)\end{array}$ & $\begin{array}{c}0.0073 * * * \\
(0.0004)\end{array}$ & $\begin{array}{c}0.0181^{* * *} \\
(0.0003)\end{array}$ & $\begin{array}{c}0.0195 * * * \\
(0.0012)\end{array}$ & $\begin{array}{c}0.0200 * * * \\
(0.0004)\end{array}$ \\
\hline YSM Squared & $\begin{array}{c}-0.0002 * * * \\
(0.0000)\end{array}$ & $\begin{array}{c}-0.0001 * * * \\
(0.0000)\end{array}$ & $\begin{array}{c}-0.0002 * * * \\
(0.0000)\end{array}$ & $\begin{array}{c}-0.0001^{* * *} \\
(0.0000)\end{array}$ & $\begin{array}{c}-0.0002 * * * \\
(0.0000)\end{array}$ \\
\hline Kids & $\begin{array}{c}-0.0214 * * * \\
(0.0018)\end{array}$ & $\begin{array}{l}-0.0002 \\
(0.0024)\end{array}$ & $\begin{array}{c}-0.0268 * * * \\
(0.0021)\end{array}$ & $\begin{array}{l}-0.0164 * \\
(0.0072)\end{array}$ & $\begin{array}{c}-0.0306^{* * *} \\
(0.0025)\end{array}$ \\
\hline Catholic Missionary & $\begin{array}{c}-0.1128 * * * \\
(0.0054)\end{array}$ & $\begin{array}{l}-0.0120 \\
(0.0067)\end{array}$ & $\begin{array}{c}-0.1051 * * * \\
(0.0045)\end{array}$ & $\begin{array}{c}-0.0873 * \\
(0.0346)\end{array}$ & $\begin{array}{c}-0.0257 * * * \\
(0.0070)\end{array}$ \\
\hline Catholic*Schooling & $\begin{array}{c}0.0045^{* * * *} \\
(0.0003)\end{array}$ & $\begin{array}{l}0.0009 * \\
(0.0004)\end{array}$ & $\begin{array}{c}0.0041^{* * *} \\
(0.0003)\end{array}$ & $\begin{array}{c}0.0059 * * \\
(0.0019)\end{array}$ & $\begin{array}{c}-0.0016^{* * *} \\
(0.0005)\end{array}$ \\
\hline Catholic*YSM & $\begin{array}{c}0.0016^{* * * *} \\
(0.0001)\end{array}$ & $\begin{array}{l}-0.0001 \\
(0.0001)\end{array}$ & $\begin{array}{c}0.0015^{* * *} \\
(0.0001)\end{array}$ & $\begin{array}{c}0.0011 \\
(0.0006)\end{array}$ & $\begin{array}{c}0.0011^{* * * *} \\
(0.0001)\end{array}$ \\
\hline Constant & $\begin{array}{c}0.1941^{* * * *} \\
(0.0098)\end{array}$ & $\begin{array}{c}0.7327 * * * \\
(0.0132)\end{array}$ & $\begin{array}{c}0.1845^{* * *} \\
(0.0095)\end{array}$ & $\begin{array}{c}0.3857 * * * \\
(0.0337)\end{array}$ & $\begin{array}{l}-0.0201 \\
(0.0147)\end{array}$ \\
\hline Observations & 325,280 & 50,634 & 274,646 & 22,713 & 194,598 \\
\hline R-squared & 0.3214 & 0.0926 & 0.3283 & 0.3230 & 0.3252 \\
\hline Adj R-sq & 0.321 & 0.0924 & 0.328 & 0.323 & 0.325 \\
\hline Mean & 0.703 & 0.956 & 0.657 & 0.690 & 0.614 \\
\hline$\underline{\text { Standard Deviation }}$ & 0.457 & 0.204 & 0.475 & 0.463 & 0.487 \\
\hline
\end{tabular}

Robust standard errors in parentheses

$* * * \mathrm{p}<0.001, * * \mathrm{p}<0.01, * \mathrm{p}<0.05$

Year fixed effects variables included in the equation, but not shown in Table.

Notes: Foreign-born persons age 25 to 64 years who worked in the prior year.

Source: U.S. Bureau of the Census, American Community Survey, PUMS, 2005-09 
Table A-7: Analysis of English Language Proficiency Among Foreign-Born Adult Males by Origin Country Colonial Heritage: Protestant Missionary Only

American Community Survey, 2005-09

(Dependent Variable: GoodEnglish)

\begin{tabular}{|c|c|c|c|c|c|}
\hline VARIABLES & $\begin{array}{l}(1) \\
\text { All }\end{array}$ & $\begin{array}{c}(2) \\
\text { UK/US }\end{array}$ & $\begin{array}{c}(3) \\
\text { Non UK/US }\end{array}$ & $\begin{array}{c}\text { (4) } \\
\text { French }\end{array}$ & $\begin{array}{c}(5) \\
\text { Spanish }\end{array}$ \\
\hline Married Spouse Present & $\begin{array}{c}0.0575^{* * *} \\
(0.0017)\end{array}$ & $\begin{array}{c}0.0013 \\
(0.0025)\end{array}$ & $\begin{array}{c}0.0571^{* * *} \\
(0.0019)\end{array}$ & $\begin{array}{c}0.0029 \\
(0.0061)\end{array}$ & $\begin{array}{c}0.0658 * * * \\
(0.0022)\end{array}$ \\
\hline Age at Migration & $\begin{array}{c}-0.0063^{* * *} \\
(0.0001)\end{array}$ & $\begin{array}{c}-0.0025^{* * *} \\
(0.0001)\end{array}$ & $\begin{array}{c}-0.0073 * * * \\
(0.0001)\end{array}$ & $\begin{array}{c}-0.0108 * * * \\
(0.0003)\end{array}$ & $\begin{array}{c}-0.0068^{* * * *} \\
(0.0001)\end{array}$ \\
\hline Schooling & $\begin{array}{c}0.0513 * * * \\
(0.0002)\end{array}$ & $\begin{array}{c}0.0204^{* * * *} \\
(0.0007)\end{array}$ & $\begin{array}{c}0.0464^{* * *} \\
(0.0003)\end{array}$ & $\begin{array}{c}0.0354 * * * \\
(0.0009)\end{array}$ & $\begin{array}{c}0.0454^{* * *} \\
(0.0006)\end{array}$ \\
\hline Years Since Migration & $\begin{array}{c}0.0219 * * * \\
(0.0002)\end{array}$ & $\begin{array}{c}0.0060^{* * * *} \\
(0.0004)\end{array}$ & $\begin{array}{c}0.0251^{* * *} \\
(0.0002)\end{array}$ & $\begin{array}{c}0.0184^{* * *} \\
(0.0010)\end{array}$ & $\begin{array}{c}0.0269 * * * \\
(0.0003)\end{array}$ \\
\hline YSM Squared & $\begin{array}{c}-0.0002 * * * \\
(0.0000)\end{array}$ & $\begin{array}{c}-0.0001^{* * *} \\
(0.0000)\end{array}$ & $\begin{array}{c}-0.0002^{* * *} \\
(0.0000)\end{array}$ & $\begin{array}{c}-0.0001^{* * *} \\
(0.0000)\end{array}$ & $\begin{array}{c}-0.0003^{* * *} \\
(0.0000)\end{array}$ \\
\hline Protestant Missionary & $\begin{array}{c}0.3699 * * * \\
(0.0083)\end{array}$ & $\begin{array}{c}0.1245^{* * *} \\
(0.0085)\end{array}$ & $\begin{array}{c}0.1961^{* * *} \\
(0.0118)\end{array}$ & $\begin{array}{c}0.2697 * * * \\
(0.0316)\end{array}$ & $\begin{array}{c}0.2054^{* * *} \\
(0.0279)\end{array}$ \\
\hline Protestant*Schooling & $\begin{array}{c}-0.0159 * * * \\
(0.0005)\end{array}$ & $\begin{array}{c}-0.0063^{* * *} \\
(0.0005)\end{array}$ & $\begin{array}{c}-0.0058 * * * \\
(0.0007)\end{array}$ & $\begin{array}{c}-0.0090 * * * \\
(0.0018)\end{array}$ & $\begin{array}{c}-0.0077^{* * * *} \\
(0.0021)\end{array}$ \\
\hline Protestant*YSM & $\begin{array}{c}-0.0036^{* * *} \\
(0.0001)\end{array}$ & $\begin{array}{c}-0.0007^{* * *} \\
(0.0001)\end{array}$ & $\begin{array}{c}-0.0026^{* * *} \\
(0.0001)\end{array}$ & $\begin{array}{c}-0.0029 * * * \\
(0.0004)\end{array}$ & $\begin{array}{l}-0.0011^{*} \\
(0.0005)\end{array}$ \\
\hline Constant & $\begin{array}{c}-0.0462 * * * \\
(0.0052)\end{array}$ & $\begin{array}{c}0.6653 * * * \\
(0.0132)\end{array}$ & $\begin{array}{l}-0.0002 \\
(0.0059)\end{array}$ & $\begin{array}{c}0.4581^{* * *} \\
(0.0225)\end{array}$ & $\begin{array}{c}-0.0485^{* * *} \\
(0.0089)\end{array}$ \\
\hline Observations & 415,061 & 64,052 & 351,009 & 26,343 & 263,437 \\
\hline R-squared & 0.3040 & 0.1032 & 0.2854 & 0.2740 & 0.2632 \\
\hline Adj R-sq & 0.304 & 0.103 & 0.285 & 0.274 & 0.263 \\
\hline Mean & 0.665 & 0.960 & 0.615 & 0.778 & 0.564 \\
\hline Standard Deviation & 0.472 & 0.195 & 0.487 & 0.415 & 0.496 \\
\hline
\end{tabular}

Robust standard errors in parentheses

$* * * \mathrm{p}<0.001, * * \mathrm{p}<0.01, * \mathrm{p}<0.05$

Year fixed effects variables included in the equation, but not shown in Table.

Notes: Foreign-born persons age 25 to 64 years who worked in the prior year.

Source: U.S. Bureau of the Census, American Community Survey, PUMS, 2005-09 
Table A-8: Analysis of English Language Proficiency Among Foreign-Born Adult Females by Origin Country Colonial Heritage: Protestant Missionary Only

American Community Survey, 2005-09

(Dependent Variable: GoodEnglish)

\begin{tabular}{|c|c|c|c|c|c|}
\hline & (1) & (2) & (3) & (4) & (5) \\
\hline VARIABLES & All & UK/US & Non UK/US & French & Spanish \\
\hline Married Spouse Present & $\begin{array}{c}0.0271 * * * \\
(0.0018)\end{array}$ & $\begin{array}{c}-0.0219 * * * \\
(0.0024)\end{array}$ & $\begin{array}{c}0.0315^{* * *} \\
(0.0020)\end{array}$ & $\begin{array}{l}-0.0123 \\
(0.0074)\end{array}$ & $\begin{array}{c}0.0352 * * * \\
(0.0024)\end{array}$ \\
\hline Age at Migration & $\begin{array}{c}-0.0063^{* * *} \\
(0.0001)\end{array}$ & $\begin{array}{c}-0.0018 * * * \\
(0.0001)\end{array}$ & $\begin{array}{c}-0.0074 * * * \\
(0.0001)\end{array}$ & $\begin{array}{c}-0.0109 * * * \\
(0.0004)\end{array}$ & $\begin{array}{c}-0.0068^{* * *} \\
(0.0001)\end{array}$ \\
\hline Schooling & $\begin{array}{c}0.0582 * * * \\
(0.0003)\end{array}$ & $\begin{array}{c}0.0263 * * * \\
(0.0009)\end{array}$ & $\begin{array}{c}0.0550 * * * \\
(0.0003)\end{array}$ & $\begin{array}{c}0.0387 * * * \\
(0.0008)\end{array}$ & $\begin{array}{c}0.0582 * * * \\
(0.0006)\end{array}$ \\
\hline Years Since Migration & $\begin{array}{c}0.0185^{* * *} \\
(0.0002)\end{array}$ & $\begin{array}{c}0.0071 * * * \\
(0.0004)\end{array}$ & $\begin{array}{c}0.0209 * * * \\
(0.0003)\end{array}$ & $\begin{array}{c}0.0213 * * * \\
(0.0011)\end{array}$ & $\begin{array}{c}0.0227 * * * \\
(0.0003)\end{array}$ \\
\hline YSM Squared & $\begin{array}{c}-0.0001^{* * * *} \\
(0.0000)\end{array}$ & $\begin{array}{c}-0.0001 * * * \\
(0.0000)\end{array}$ & $\begin{array}{c}-0.0002 * * * \\
(0.0000)\end{array}$ & $\begin{array}{c}-0.0001^{* * * *} \\
(0.0000)\end{array}$ & $\begin{array}{c}-0.0002^{* * *} \\
(0.0000)\end{array}$ \\
\hline Kids & $\begin{array}{c}-0.0247^{* * *} \\
(0.0018)\end{array}$ & $\begin{array}{l}-0.0003 \\
(0.0023)\end{array}$ & $\begin{array}{c}-0.0301 * * * \\
(0.0021)\end{array}$ & $\begin{array}{c}-0.0172 * \\
(0.0071)\end{array}$ & $\begin{array}{c}-0.0301^{* * *} \\
(0.0026)\end{array}$ \\
\hline Protestant Missionary & $\begin{array}{c}0.4338 * * * \\
(0.0086)\end{array}$ & $\begin{array}{c}0.1709 * * * \\
(0.0087)\end{array}$ & $\begin{array}{c}0.2413^{* * *} \\
(0.0141)\end{array}$ & $\begin{array}{c}0.4059 * * * \\
(0.0420)\end{array}$ & $\begin{array}{c}0.3227 * * * \\
(0.0308)\end{array}$ \\
\hline Protestant*Schooling & $\begin{array}{c}-0.0201^{* * *} \\
(0.0005)\end{array}$ & $\begin{array}{c}-0.0088 * * * \\
(0.0005)\end{array}$ & $\begin{array}{c}-0.0092 * * * \\
(0.0009)\end{array}$ & $\begin{array}{c}-0.0122 * * * \\
(0.0025)\end{array}$ & $\begin{array}{c}-0.0146^{* * *} \\
(0.0021)\end{array}$ \\
\hline Protestant*YSM & $\begin{array}{c}-0.0037^{* * * *} \\
(0.0001)\end{array}$ & $\begin{array}{c}-0.0012^{* * *} \\
(0.0001)\end{array}$ & $\begin{array}{c}-0.0026 * * * \\
(0.0002)\end{array}$ & $\begin{array}{c}-0.0056 * * * \\
(0.0005)\end{array}$ & $\begin{array}{c}-0.0024^{* * *} \\
(0.0005)\end{array}$ \\
\hline Constant & $\begin{array}{c}-0.0872 * * * \\
(0.0062)\end{array}$ & $\begin{array}{c}0.5391^{* * *} \\
(0.0168)\end{array}$ & $\begin{array}{c}-0.0396 * * * \\
(0.0073)\end{array}$ & $\begin{array}{c}0.3101 * * * \\
(0.0251)\end{array}$ & $\begin{array}{c}-0.1440 * * * \\
(0.0105)\end{array}$ \\
\hline Observations & 325,280 & 50,634 & 274,646 & 22,713 & 194,598 \\
\hline R-squared & 0.3372 & 0.1392 & 0.3265 & 0.3365 & 0.3246 \\
\hline Adj R-sq & 0.337 & 0.139 & 0.326 & 0.336 & 0.325 \\
\hline Mean & 0.703 & 0.956 & 0.657 & 0.690 & 0.614 \\
\hline Standard Deviation & 0.457 & 0.204 & 0.475 & 0.463 & 0.487 \\
\hline
\end{tabular}

Robust standard errors in parentheses

$* * * \mathrm{p}<0.001, * * \mathrm{p}<0.01, * \mathrm{p}<0.05$

Year fixed effects variables included in the equation, but not shown in Table.

Notes: Foreign-born persons age 25 to 64 years who worked in the prior year.

Source: U.S. Bureau of the Census, American Community Survey, PUMS, 2005-09 
Table A-9: Analysis of Earnings Among Foreign-Born Adult Males, by Origin Country Colonial Heritage ACS 2005-09

(Dependent Variable: Natural Logarithm of Earnings, in 2009 dollars)

\begin{tabular}{|c|c|c|c|c|c|}
\hline VARIABLES & $\begin{array}{l}(1) \\
\text { All } \\
\end{array}$ & $\begin{array}{c}(2) \\
\text { UK/US }\end{array}$ & $\begin{array}{c}(3) \\
\text { Non UK/US }\end{array}$ & $\begin{array}{c}\text { (4) } \\
\text { French }\end{array}$ & $\begin{array}{c}\text { (5) } \\
\text { Spanish }\end{array}$ \\
\hline Schooling & $\begin{array}{c}0.0750 * * * \\
(0.0008)\end{array}$ & $\begin{array}{c}0.1088 * * * \\
(0.0020)\end{array}$ & $\begin{array}{c}0.0626 * * * \\
(0.0009)\end{array}$ & $\begin{array}{c}0.0439 * * * \\
(0.0032)\end{array}$ & $\begin{array}{c}0.0152^{* * *} \\
(0.0018)\end{array}$ \\
\hline Language & $\begin{array}{c}0.1892 * * * \\
(0.0033)\end{array}$ & $\begin{array}{c}0.1999 * * * \\
(0.0279)\end{array}$ & $\begin{array}{c}0.1870 * * * \\
(0.0033)\end{array}$ & $\begin{array}{c}0.1371 * * * \\
(0.0158)\end{array}$ & $\begin{array}{c}0.1839 * * * \\
(0.0034)\end{array}$ \\
\hline Married Spouse Present & $\begin{array}{c}0.1802 * * * \\
(0.0028)\end{array}$ & $\begin{array}{c}0.2557 * * * \\
(0.0086)\end{array}$ & $\begin{array}{c}0.1601^{* * *} \\
(0.0029)\end{array}$ & $\begin{array}{c}0.1641^{* * *} \\
(0.0125)\end{array}$ & $\begin{array}{c}0.1545 * * * \\
(0.0032)\end{array}$ \\
\hline Experience & $\begin{array}{c}0.0109 * * * \\
(0.0005)\end{array}$ & $\begin{array}{c}0.0007 \\
(0.0016)\end{array}$ & $\begin{array}{c}0.0150 * * * \\
(0.0006)\end{array}$ & $\begin{array}{c}0.0042 \\
(0.0022)\end{array}$ & $\begin{array}{c}0.0142 * * * \\
(0.0006)\end{array}$ \\
\hline Experience Squared & $\begin{array}{c}-0.0002^{* * *} \\
(0.0000)\end{array}$ & $\begin{array}{l}-0.0001^{*} \\
(0.0000)\end{array}$ & $\begin{array}{c}-0.0003^{* * * *} \\
(0.0000)\end{array}$ & $\begin{array}{c}-0.0001 * * \\
(0.0000)\end{array}$ & $\begin{array}{c}-0.0002^{* * *} \\
(0.0000)\end{array}$ \\
\hline South & $\begin{array}{c}-0.0494^{* * *} \\
(0.0027)\end{array}$ & $\begin{array}{c}-0.0873 * * * \\
(0.0077)\end{array}$ & $\begin{array}{c}-0.0442^{* * * *} \\
(0.0029)\end{array}$ & $\begin{array}{l}-0.0026 \\
(0.0120)\end{array}$ & $\begin{array}{c}-0.0519 * * * \\
(0.0031)\end{array}$ \\
\hline Year Since Migration & $\begin{array}{c}0.0139 * * * \\
(0.0004)\end{array}$ & $\begin{array}{c}0.0217 * * * \\
(0.0013)\end{array}$ & $\begin{array}{c}0.0161^{* * *} \\
(0.0005)\end{array}$ & $\begin{array}{c}0.0246 * * * \\
(0.0025)\end{array}$ & $\begin{array}{c}0.0153^{* * *} \\
(0.0007)\end{array}$ \\
\hline YSM Squared & $\begin{array}{c}-0.0001^{* * *} \\
(0.0000)\end{array}$ & $\begin{array}{c}-0.0003^{* * *} \\
(0.0000)\end{array}$ & $\begin{array}{c}-0.0001^{* * *} \\
(0.0000)\end{array}$ & $\begin{array}{c}-0.0002^{* * *} \\
(0.0001)\end{array}$ & $\begin{array}{c}-0.0001^{* * *} \\
(0.0000)\end{array}$ \\
\hline Ln Weeks Worked & $\begin{array}{c}0.9891 * * * \\
(0.0052)\end{array}$ & $\begin{array}{c}1.0755 * * * \\
(0.0148)\end{array}$ & $\begin{array}{c}0.9718^{* * *} \\
(0.0055)\end{array}$ & $\begin{array}{c}1.0225 * * * \\
(0.0210)\end{array}$ & $\begin{array}{c}0.9416 * * * \\
(0.0061)\end{array}$ \\
\hline Catholic Missionary & $\begin{array}{c}0.1906 * * * \\
(0.0062)\end{array}$ & $\begin{array}{c}0.0023 \\
(0.0100)\end{array}$ & $\begin{array}{c}0.1692^{* * *} \\
(0.0064)\end{array}$ & $\begin{array}{c}-0.2712^{* * * *} \\
(0.0762)\end{array}$ & $\begin{array}{c}-0.0374 * * * \\
(0.0094)\end{array}$ \\
\hline Catholic*Schooling & $\begin{array}{c}-0.0191 * * * \\
(0.0004)\end{array}$ & $\begin{array}{l}-0.0010 \\
(0.0007)\end{array}$ & $\begin{array}{c}-0.0161^{* * *} \\
(0.0004)\end{array}$ & $\begin{array}{c}0.0161^{* * *} \\
(0.0048)\end{array}$ & $\begin{array}{c}0.0042 * * * \\
(0.0007)\end{array}$ \\
\hline Catholic*YSM & $\begin{array}{l}0.0004^{* *} \\
(0.0001)\end{array}$ & $\begin{array}{c}0.0002 \\
(0.0002)\end{array}$ & $\begin{array}{c}-0.0007 * * * \\
(0.0002)\end{array}$ & $\begin{array}{l}0.0049 * \\
(0.0021)\end{array}$ & $\begin{array}{c}-0.0007 * * \\
(0.0002)\end{array}$ \\
\hline Protestant Missionary & $\begin{array}{c}-0.2682^{* * *} \\
(0.0148)\end{array}$ & $\begin{array}{c}0.1006 * * * \\
(0.0212)\end{array}$ & $\begin{array}{c}-0.3755^{* * *} \\
(0.0276)\end{array}$ & $\begin{array}{l}-0.0382 \\
(0.0839)\end{array}$ & $\begin{array}{c}-0.5613^{* * *} \\
(0.0474)\end{array}$ \\
\hline Protestant*Schooling & $\begin{array}{c}0.0256 * * * \\
(0.0010)\end{array}$ & $\begin{array}{c}-0.0063^{* * *} \\
(0.0014)\end{array}$ & $\begin{array}{c}0.0399 * * * \\
(0.0019)\end{array}$ & $\begin{array}{c}0.0167 * * \\
(0.0053)\end{array}$ & $\begin{array}{c}0.0594 * * * \\
(0.0036)\end{array}$ \\
\hline Protestant*YSM & $\begin{array}{c}-0.0011^{* * *} \\
(0.0002)\end{array}$ & $\begin{array}{l}-0.0010^{*} \\
(0.0004)\end{array}$ & $\begin{array}{c}-0.0023^{* * *} \\
(0.0004)\end{array}$ & $\begin{array}{c}-0.0064^{* * *} \\
(0.0019)\end{array}$ & $\begin{array}{l}-0.0007 \\
(0.0010)\end{array}$ \\
\hline Constant & $\begin{array}{c}5.0325 * * * \\
(0.0235)\end{array}$ & $\begin{array}{c}4.3438 * * * \\
(0.0678)\end{array}$ & $\begin{array}{c}5.1454 * * * \\
(0.0255)\end{array}$ & $\begin{array}{c}5.2669 * * * \\
(0.0979)\end{array}$ & $\begin{array}{c}5.7424 * * * \\
(0.0338)\end{array}$ \\
\hline Observations & 415,061 & 64,052 & 351,009 & 26,343 & 263,437 \\
\hline R-squared & 0.4161 & 0.4083 & 0.4033 & 0.3864 & 0.3861 \\
\hline Adj R-sq & 0.416 & 0.408 & 0.403 & 0.386 & 0.386 \\
\hline Mean & 10.27 & 10.66 & 10.20 & 10.43 & 10.11 \\
\hline Standard Deviation & 0.896 & 0.987 & 0.862 & 0.924 & 0.799 \\
\hline
\end{tabular}

Robust standard errors in parentheses

$* * * \mathrm{p}<0.001, * * \mathrm{p}<0.01, * \mathrm{p}<0.05$

Year fixed effects variables included, but not shown in Table

Notes: Foreign-born persons age 25 to 64 years who worked in the prior year.

Source: U.S. Bureau of the Census, American Community Survey, PUMS, 2005-09 
Table A-10: Analysis of Earnings Among Foreign-Born Adult Females, by Origin Country Colonial Heritage ACS 2005-09

(Dependent Variable: Natural Logarithm of Earnings, in 2009 dollars)

\begin{tabular}{|c|c|c|c|c|c|}
\hline VARIABLES & $\begin{array}{l}\text { (1) } \\
\text { All }\end{array}$ & $\begin{array}{c}(2) \\
\text { UK/US }\end{array}$ & $\begin{array}{c}\text { (3) } \\
\text { Non UK/US }\end{array}$ & $\begin{array}{c}(4) \\
\text { French }\end{array}$ & $\begin{array}{c}(5) \\
\text { Spanish }\end{array}$ \\
\hline Schooling & $\begin{array}{c}0.0714^{* * * *} \\
(0.0009)\end{array}$ & $\begin{array}{c}0.0961^{* * * *} \\
(0.0023)\end{array}$ & $\begin{array}{c}0.0633 * * * \\
(0.0011)\end{array}$ & $\begin{array}{c}0.0198 * * * \\
(0.0030)\end{array}$ & $\begin{array}{c}0.0506^{* * *} \\
(0.0021)\end{array}$ \\
\hline Language & $\begin{array}{c}0.2417 * * * \\
(0.0041)\end{array}$ & $\begin{array}{c}0.1591 * * * \\
(0.0242)\end{array}$ & $\begin{array}{c}0.2384 * * * \\
(0.0042)\end{array}$ & $\begin{array}{c}0.1512 * * * \\
(0.0159)\end{array}$ & $\begin{array}{c}0.2631 * * * \\
(0.0047)\end{array}$ \\
\hline Married Spouse Present & $\begin{array}{c}0.0254 * * * \\
(0.0033)\end{array}$ & $\begin{array}{c}0.0114 \\
(0.0087)\end{array}$ & $\begin{array}{c}0.0200 * * * \\
(0.0035)\end{array}$ & $\begin{array}{c}0.0399 * * \\
(0.0138)\end{array}$ & $\begin{array}{c}0.0239 * * * \\
(0.0040)\end{array}$ \\
\hline Experience & $\begin{array}{l}-0.0001 \\
(0.0006)\end{array}$ & $\begin{array}{c}-0.0067 * * * \\
(0.0016)\end{array}$ & $\begin{array}{c}0.0027 * * * \\
(0.0007)\end{array}$ & $\begin{array}{c}-0.0131 * * * \\
(0.0023)\end{array}$ & $\begin{array}{c}0.0059 * * * \\
(0.0008)\end{array}$ \\
\hline Experience Squared & $\begin{array}{c}0.0000 \\
(0.0000)\end{array}$ & $\begin{array}{c}0.0001^{* * *} \\
(0.0000)\end{array}$ & $\begin{array}{c}-0.0000 * * * \\
(0.0000)\end{array}$ & $\begin{array}{c}0.0001^{* * *} \\
(0.0000)\end{array}$ & $\begin{array}{c}-0.0001^{* * *} \\
(0.0000)\end{array}$ \\
\hline South & $\begin{array}{c}-0.0858 * * * \\
(0.0033)\end{array}$ & $\begin{array}{c}-0.0586 * * * \\
(0.0084)\end{array}$ & $\begin{array}{c}-0.0879 * * * \\
(0.0035)\end{array}$ & $\begin{array}{c}-0.0378^{* *} \\
(0.0131)\end{array}$ & $\begin{array}{c}-0.1026^{* * * *} \\
(0.0040)\end{array}$ \\
\hline Year Since Migration & $\begin{array}{c}0.0179 * * * \\
(0.0005)\end{array}$ & $\begin{array}{c}0.0202 * * * \\
(0.0014)\end{array}$ & $\begin{array}{c}0.0182 * * * \\
(0.0006)\end{array}$ & $\begin{array}{c}0.0249 * * * \\
(0.0027)\end{array}$ & $\begin{array}{c}0.0142 * * * \\
(0.0008)\end{array}$ \\
\hline YSM Squared & $\begin{array}{c}-0.0002 * * * \\
(0.0000)\end{array}$ & $\begin{array}{c}-0.0002 * * * \\
(0.0000)\end{array}$ & $\begin{array}{c}-0.0002^{* * *} \\
(0.0000)\end{array}$ & $\begin{array}{c}-0.0004^{* * *} \\
(0.0001)\end{array}$ & $\begin{array}{c}-0.0002^{* * *} \\
(0.0000)\end{array}$ \\
\hline Ln Weeks Worked & $\begin{array}{c}1.0669 * * * \\
(0.0040)\end{array}$ & $\begin{array}{c}1.1329 * * * \\
(0.0119)\end{array}$ & $\begin{array}{c}1.0560 * * * \\
(0.0042)\end{array}$ & $\begin{array}{c}1.0425^{* * *} \\
(0.0184)\end{array}$ & $\begin{array}{c}1.0369 * * * \\
(0.0047)\end{array}$ \\
\hline Kids & $\begin{array}{c}-0.0398 * * * \\
(0.0035)\end{array}$ & $\begin{array}{c}0.0016 \\
(0.0093)\end{array}$ & $\begin{array}{c}-0.0481^{* * *} \\
(0.0038)\end{array}$ & $\begin{array}{l}-0.0238 \\
(0.0143)\end{array}$ & $\begin{array}{c}-0.0586^{* * *} \\
(0.0043)\end{array}$ \\
\hline Catholic Missionary & $\begin{array}{c}0.0728 * * * \\
(0.0065)\end{array}$ & $\begin{array}{c}0.0083 \\
(0.0098)\end{array}$ & $\begin{array}{c}0.0543 * * * \\
(0.0078)\end{array}$ & $\begin{array}{c}-0.5873^{* * *} \\
(0.0707)\end{array}$ & $\begin{array}{c}0.0113 \\
(0.0122)\end{array}$ \\
\hline Catholic*Schooling & $\begin{array}{c}-0.0097 * * * \\
(0.0004)\end{array}$ & $\begin{array}{l}-0.0014^{*} \\
(0.0007)\end{array}$ & $\begin{array}{c}-0.0094^{* * *} \\
(0.0005)\end{array}$ & $\begin{array}{c}0.0375 * * * \\
(0.0045)\end{array}$ & $\begin{array}{c}-0.0057^{* * *} \\
(0.0009)\end{array}$ \\
\hline Catholic*YSM & $\begin{array}{l}0.0003 * \\
(0.0001)\end{array}$ & $\begin{array}{l}-0.0000 \\
(0.0002)\end{array}$ & $\begin{array}{c}0.0001 \\
(0.0002)\end{array}$ & $\begin{array}{c}0.0086 * * * \\
(0.0022)\end{array}$ & $\begin{array}{c}0.0002 \\
(0.0003)\end{array}$ \\
\hline Protestant Missionary & $\begin{array}{c}-0.2481 * * * \\
(0.0150)\end{array}$ & $\begin{array}{c}-0.0450 * \\
(0.0209)\end{array}$ & $\begin{array}{c}-0.4837 * * * \\
(0.0382)\end{array}$ & $\begin{array}{l}-0.1019 \\
(0.1076)\end{array}$ & $\begin{array}{c}-0.7064 * * * \\
(0.0554)\end{array}$ \\
\hline Protestant*Schooling & $\begin{array}{c}0.0219 * * * \\
(0.0010)\end{array}$ & $\begin{array}{c}0.0037 * * \\
(0.0014)\end{array}$ & $\begin{array}{c}0.0384^{* * *} \\
(0.0027)\end{array}$ & $\begin{array}{c}0.0115 \\
(0.0069)\end{array}$ & $\begin{array}{c}0.0572 * * * \\
(0.0040)\end{array}$ \\
\hline Protestant*YSM & $\begin{array}{l}-0.0001 \\
(0.0002)\end{array}$ & $\begin{array}{l}-0.0002 \\
(0.0003)\end{array}$ & $\begin{array}{c}0.0001 \\
(0.0005)\end{array}$ & $\begin{array}{c}-0.0080 * * * \\
(0.0021)\end{array}$ & $\begin{array}{l}0.0027 * * \\
(0.0010)\end{array}$ \\
\hline Constant & $\begin{array}{c}4.6636 * * * \\
(0.0210)\end{array}$ & $\begin{array}{c}4.2453 * * * \\
(0.0615)\end{array}$ & $\begin{array}{c}4.7991 * * * \\
(0.0245)\end{array}$ & $\begin{array}{c}5.5608 * * * \\
(0.0878)\end{array}$ & $\begin{array}{c}4.9898 * * * \\
(0.0350)\end{array}$ \\
\hline Observations & 325,280 & 50,634 & 274,646 & 22,713 & 194,598 \\
\hline R-squared & 0.4847 & 0.4421 & 0.4848 & 0.3935 & 0.5024 \\
\hline Adj R-sq & 0.485 & 0.442 & 0.485 & 0.393 & 0.502 \\
\hline Mean & 9.897 & 10.22 & 9.838 & 10.01 & 9.747 \\
\hline Standard Deviation & 1.020 & 1.018 & 1.009 & 0.972 & 0.979 \\
\hline
\end{tabular}

Robust standard errors in parentheses

$* * * \mathrm{p}<0.001, * * \mathrm{p}<0.01, * \mathrm{p}<0.05$

Year fixed effects variables included, but not shown in Table

Notes: Foreign-born persons age 25 to 64 years who worked in the prior year.

Source: U.S. Bureau of the Census, American Community Survey, PUMS, 2005-09 
Table A-11: Analysis of Earnings Among Foreign-Born Adult Males, by Origin Country Colonial Heritage: Catholic Missionaries Only

ACS 2005-09

(Dependent Variable: Natural Logarithm of Earnings, in 2009 dollars)

\begin{tabular}{|c|c|c|c|c|c|}
\hline VARIABLES & $\begin{array}{l}(1) \\
\text { All }\end{array}$ & $\begin{array}{c}(2) \\
\text { UK/US }\end{array}$ & $\begin{array}{c}(3) \\
\text { Non UK/US }\end{array}$ & $\begin{array}{l}\text { (4) } \\
\text { French }\end{array}$ & $\begin{array}{c}\text { (5) } \\
\text { Spanish }\end{array}$ \\
\hline Schooling & $\begin{array}{c}0.0810^{* * *} \\
(0.0008)\end{array}$ & $\begin{array}{c}0.1050^{* * *} \\
(0.0016)\end{array}$ & $\begin{array}{c}0.0712^{* * *} \\
(0.0008)\end{array}$ & $\begin{array}{c}0.0379 * * * \\
(0.0028)\end{array}$ & $\begin{array}{c}0.0331 * * * \\
(0.0014)\end{array}$ \\
\hline Language & $\begin{array}{c}0.1928 * * * \\
(0.0032)\end{array}$ & $\begin{array}{c}0.2112^{* * *} \\
(0.0269)\end{array}$ & $\begin{array}{c}0.1900 * * * \\
(0.0033)\end{array}$ & $\begin{array}{c}0.1482 * * * \\
(0.0154)\end{array}$ & $\begin{array}{c}0.1847 * * * \\
(0.0034)\end{array}$ \\
\hline Married Spouse Present & $\begin{array}{c}0.1819 * * * \\
(0.0028)\end{array}$ & $\begin{array}{c}0.2573^{* * *} \\
(0.0086)\end{array}$ & $\begin{array}{c}0.1632 * * * \\
(0.0029)\end{array}$ & $\begin{array}{c}0.1661 * * * \\
(0.0125)\end{array}$ & $\begin{array}{c}0.1553 * * * \\
(0.0032)\end{array}$ \\
\hline Experience & $\begin{array}{c}0.0107 * * * \\
(0.0005)\end{array}$ & $\begin{array}{c}0.0004 \\
(0.0016)\end{array}$ & $\begin{array}{c}0.0149 * * * \\
(0.0006)\end{array}$ & $\begin{array}{c}0.0040 \\
(0.0022)\end{array}$ & $\begin{array}{c}0.0144^{* * *} \\
(0.0006)\end{array}$ \\
\hline Experience Squared & $\begin{array}{c}-0.0002 * * * \\
(0.0000)\end{array}$ & $\begin{array}{c}-0.0001^{*} \\
(0.0000)\end{array}$ & $\begin{array}{c}-0.0002 * * * \\
(0.0000)\end{array}$ & $\begin{array}{l}-0.0001^{*} \\
(0.0000)\end{array}$ & $\begin{array}{c}-0.0002^{* * *} \\
(0.0000)\end{array}$ \\
\hline South & $\begin{array}{c}-0.0484^{* * *} \\
(0.0027)\end{array}$ & $\begin{array}{c}-0.0883 * * * \\
(0.0077)\end{array}$ & $\begin{array}{c}-0.0447 * * * \\
(0.0029)\end{array}$ & $\begin{array}{c}-0.0012 \\
(0.0120)\end{array}$ & $\begin{array}{c}-0.0468 * * * \\
(0.0031)\end{array}$ \\
\hline Year Since Migration & $\begin{array}{c}0.0137 * * * \\
(0.0004)\end{array}$ & $\begin{array}{c}0.0213^{* * *} \\
(0.0013)\end{array}$ & $\begin{array}{c}0.0152^{* * *} \\
(0.0005)\end{array}$ & $\begin{array}{c}0.0259 * * * \\
(0.0023)\end{array}$ & $\begin{array}{c}0.0145^{* * *} \\
(0.0006)\end{array}$ \\
\hline YSM Squared & $\begin{array}{c}-0.0001 * * * \\
(0.0000)\end{array}$ & $\begin{array}{c}-0.0003^{* * *} \\
(0.0000)\end{array}$ & $\begin{array}{c}-0.0001^{* * *} \\
(0.0000)\end{array}$ & $\begin{array}{c}-0.0002 * * * \\
(0.0001)\end{array}$ & $\begin{array}{c}-0.0001^{* * *} \\
(0.0000)\end{array}$ \\
\hline Ln Weeks Worked & $\begin{array}{c}0.9888 * * * \\
(0.0052)\end{array}$ & $\begin{array}{c}1.0750 * * * \\
(0.0148)\end{array}$ & $\begin{array}{c}0.9715^{* * *} \\
(0.0055)\end{array}$ & $\begin{array}{c}1.0217^{* * *} \\
(0.0210)\end{array}$ & $\begin{array}{c}0.9418^{* * * *} \\
(0.0061)\end{array}$ \\
\hline Catholic Missionary & $\begin{array}{c}0.1765^{* * *} \\
(0.0065)\end{array}$ & $\begin{array}{c}0.0274 * * \\
(0.0088)\end{array}$ & $\begin{array}{c}0.1580 * * * \\
(0.0064)\end{array}$ & $\begin{array}{c}-0.2962 * * * \\
(0.0519)\end{array}$ & $\begin{array}{l}-0.0200^{*} \\
(0.0089)\end{array}$ \\
\hline Catholic*Schooling & $\begin{array}{c}-0.0175^{* * *} \\
(0.0005)\end{array}$ & $\begin{array}{c}-0.0027 * * * \\
(0.0006)\end{array}$ & $\begin{array}{c}-0.0147 * * * \\
(0.0004)\end{array}$ & $\begin{array}{c}0.0298 * * * \\
(0.0031)\end{array}$ & $\begin{array}{c}0.0027^{* * *} \\
(0.0007)\end{array}$ \\
\hline Catholic*YSM & $\begin{array}{c}0.0005^{* * *} \\
(0.0001)\end{array}$ & $\begin{array}{c}-0.0001 \\
(0.0002)\end{array}$ & $\begin{array}{c}-0.0006^{* * *} \\
(0.0001)\end{array}$ & $\begin{array}{c}-0.0003 \\
(0.0011)\end{array}$ & $\begin{array}{l}-0.0006^{*} \\
(0.0002)\end{array}$ \\
\hline Constant & $\begin{array}{c}5.0325^{* * *} \\
(0.0235)\end{array}$ & $\begin{array}{c}4.4001 * * * \\
(0.0665)\end{array}$ & $\begin{array}{c}5.0638 * * * \\
(0.0249)\end{array}$ & $\begin{array}{c}5.2853 * * * \\
(0.0937)\end{array}$ & $\begin{array}{c}5.5639 * * * \\
(0.0300)\end{array}$ \\
\hline Observations & 415,061 & 64,052 & 351,009 & 26,343 & 263,437 \\
\hline R-squared & 0.4161 & 0.4079 & 0.4000 & 0.3851 & 0.3841 \\
\hline Adj R-sq & 0.416 & 0.408 & 0.400 & 0.385 & 0.384 \\
\hline Mean & 10.27 & 10.66 & 10.20 & 10.43 & 10.11 \\
\hline Standard Deviation & 0.896 & 0.987 & 0.862 & 0.924 & 0.799 \\
\hline
\end{tabular}

Robust standard errors in parentheses

$* * * \mathrm{p}<0.001,{ }^{* *} \mathrm{p}<0.01,{ }^{*} \mathrm{p}<0.05$

Year fixed effects variables included, but not shown in Table

Notes: Foreign-born persons age 25 to 64 years who worked in the prior year.

Source: U.S. Bureau of the Census, American Community Survey, PUMS, 2005-09 
Table A-12: Analysis of Earnings Among Foreign-Born Adult Females, by Origin Country Colonial Heritage: Catholic Missionaries Only

ACS 2005-09

(Dependent Variable: Natural Logarithm of Earnings, in 2009 dollars)

\begin{tabular}{|c|c|c|c|c|c|}
\hline VARIABLES & $\begin{array}{l}(1) \\
\text { All }\end{array}$ & $\begin{array}{c}(2) \\
\text { UK/US }\end{array}$ & $\begin{array}{c}(3) \\
\text { Non UK/US }\end{array}$ & $\begin{array}{c}(4) \\
\text { French }\end{array}$ & $\begin{array}{c}(5) \\
\text { Spanish }\end{array}$ \\
\hline Schooling & $\begin{array}{c}0.0765^{* * *} \\
(0.0008)\end{array}$ & $\begin{array}{c}0.0989 * * * \\
(0.0018)\end{array}$ & $\begin{array}{c}0.0707 * * * \\
(0.0010)\end{array}$ & $\begin{array}{c}0.0209^{* * *} \\
(0.0029)\end{array}$ & $\begin{array}{c}0.0684 * * * \\
(0.0017)\end{array}$ \\
\hline Language & $\begin{array}{c}0.2436 * * * \\
(0.0041)\end{array}$ & $\begin{array}{c}0.1513 * * * \\
(0.0236)\end{array}$ & $\begin{array}{c}0.2380 * * * \\
(0.0042)\end{array}$ & $\begin{array}{c}0.1449 * * * \\
(0.0155)\end{array}$ & $\begin{array}{c}0.2628 * * * \\
(0.0047)\end{array}$ \\
\hline Married Spouse Present & $\begin{array}{c}0.0239 * * * \\
(0.0033)\end{array}$ & $\begin{array}{c}0.0097 \\
(0.0086)\end{array}$ & $\begin{array}{c}0.0221^{* * *} \\
(0.0035)\end{array}$ & $\begin{array}{c}0.0401^{* *} \\
(0.0138)\end{array}$ & $\begin{array}{c}0.0249 * * * \\
(0.0040)\end{array}$ \\
\hline Experience & $\begin{array}{c}-0.0004 \\
(0.0006)\end{array}$ & $\begin{array}{c}-0.0063^{* * *} \\
(0.0016)\end{array}$ & $\begin{array}{c}0.0024^{* * *} \\
(0.0007)\end{array}$ & $\begin{array}{c}-0.0135^{* * *} \\
(0.0023)\end{array}$ & $\begin{array}{c}0.0061^{* * *} \\
(0.0008)\end{array}$ \\
\hline Experience Squared & $\begin{array}{c}0.0000 \\
(0.0000)\end{array}$ & $\begin{array}{c}0.0001^{* * *} \\
(0.0000)\end{array}$ & $\begin{array}{c}-0.0000 * * * \\
(0.0000)\end{array}$ & $\begin{array}{c}0.0002 * * * \\
(0.0000)\end{array}$ & $\begin{array}{c}-0.0001 * * * \\
(0.0000)\end{array}$ \\
\hline South & $\begin{array}{c}-0.0845^{* * *} \\
(0.0033)\end{array}$ & $\begin{array}{c}-0.0579 * * * \\
(0.0084)\end{array}$ & $\begin{array}{c}-0.0889 * * * \\
(0.0035)\end{array}$ & $\begin{array}{c}-0.0339 * * \\
(0.0132)\end{array}$ & $\begin{array}{c}-0.0990 * * * \\
(0.0040)\end{array}$ \\
\hline Year Since Migration & $\begin{array}{c}0.0181^{* * *} \\
(0.0005)\end{array}$ & $\begin{array}{c}0.0201 * * * \\
(0.0014)\end{array}$ & $\begin{array}{c}0.0180^{* * *} \\
(0.0006)\end{array}$ & $\begin{array}{c}0.0301^{* * *} \\
(0.0025)\end{array}$ & $\begin{array}{c}0.0143 * * * \\
(0.0008)\end{array}$ \\
\hline YSM Squared & $\begin{array}{c}-0.0002^{* * *} \\
(0.0000)\end{array}$ & $\begin{array}{c}-0.0002^{* * *} \\
(0.0000)\end{array}$ & $\begin{array}{c}-0.0002 * * * \\
(0.0000)\end{array}$ & $\begin{array}{c}-0.0004 * * * \\
(0.0001)\end{array}$ & $\begin{array}{c}-0.0001^{* * *} \\
(0.0000)\end{array}$ \\
\hline Ln Weeks Worked & $\begin{array}{c}1.0670 * * * \\
(0.0040)\end{array}$ & $\begin{array}{c}1.1331^{* * *} \\
(0.0119)\end{array}$ & $\begin{array}{c}1.0560 * * * \\
(0.0042)\end{array}$ & $\begin{array}{c}1.0433^{* * *} \\
(0.0184)\end{array}$ & $\begin{array}{c}1.0372 * * * \\
(0.0047)\end{array}$ \\
\hline Kids & $\begin{array}{c}-0.0397 * * * \\
(0.0035)\end{array}$ & $\begin{array}{c}0.0006 \\
(0.0093)\end{array}$ & $\begin{array}{c}-0.0477 * * * \\
(0.0038)\end{array}$ & $\begin{array}{l}-0.0238 \\
(0.0143)\end{array}$ & $\begin{array}{c}-0.0589 * * * \\
(0.0043)\end{array}$ \\
\hline Catholic Missionary & $\begin{array}{c}0.0536 * * * \\
(0.0068)\end{array}$ & $\begin{array}{l}-0.0016 \\
(0.0098)\end{array}$ & $\begin{array}{c}0.0390 * * * \\
(0.0078)\end{array}$ & $\begin{array}{c}-0.5382 * * * \\
(0.0593)\end{array}$ & $\begin{array}{c}0.0354 * * \\
(0.0118)\end{array}$ \\
\hline Catholic*Schooling & $\begin{array}{c}-0.0078 * * * \\
(0.0005)\end{array}$ & $\begin{array}{l}-0.0005 \\
(0.0007)\end{array}$ & $\begin{array}{c}-0.0080 * * * \\
(0.0005)\end{array}$ & $\begin{array}{c}0.0391^{* * *} \\
(0.0039)\end{array}$ & $\begin{array}{c}-0.0074 * * * \\
(0.0009)\end{array}$ \\
\hline Catholic*YSM & $\begin{array}{c}0.0004 * * \\
(0.0001)\end{array}$ & $\begin{array}{l}-0.0001 \\
(0.0002)\end{array}$ & $\begin{array}{c}0.0001 \\
(0.0002)\end{array}$ & $\begin{array}{c}0.0015 \\
(0.0014)\end{array}$ & $\begin{array}{c}0.0003 \\
(0.0003)\end{array}$ \\
\hline Constant & $\begin{array}{c}4.6091 * * * \\
(0.0209)\end{array}$ & $\begin{array}{c}4.2111^{* * *} \\
(0.0585)\end{array}$ & $\begin{array}{c}4.7083^{* * *} \\
(0.0232)\end{array}$ & $\begin{array}{c}5.5036^{* * *} \\
(0.0863)\end{array}$ & $\begin{array}{c}4.7664 * * * \\
(0.0304)\end{array}$ \\
\hline Observations & 325,280 & 50,634 & 274,646 & 22,713 & 194,598 \\
\hline R-squared & 0.4824 & 0.4420 & 0.4836 & 0.3920 & 0.5012 \\
\hline Adj R-sq & 0.482 & 0.442 & 0.484 & 0.392 & 0.501 \\
\hline Mean & 9.897 & 10.22 & 9.838 & 10.01 & 9.747 \\
\hline Standard Deviation & 1.020 & 1.018 & 1.009 & 0.972 & 0.979 \\
\hline
\end{tabular}

Robust standard errors in parentheses

${ }^{* * *} \mathrm{p}<0.001,{ }^{* *} \mathrm{p}<0.01,{ }^{*} \mathrm{p}<0.05$

Year fixed effects variables included, but not shown in Table

Notes: Foreign-born persons age 25 to 64 years who worked in the prior year.

Source: U.S. Bureau of the Census, American Community Survey, PUMS, 2005-09 
Table A-13: Analysis of Earnings Among Foreign-Born Adult Males, by Origin Country Colonial Heritage: Protestant Missionaries Only

ACS 2005-09

(Dependent Variable: Natural Logarithm of Earnings, in 2009 dollars)

\begin{tabular}{|c|c|c|c|c|c|}
\hline VARIABLES & $\begin{array}{l}(1) \\
\text { All }\end{array}$ & $\begin{array}{c}(2) \\
\text { UK/US }\end{array}$ & $\begin{array}{c}(3) \\
\text { Non UK/US }\end{array}$ & $\begin{array}{l}(4) \\
\text { French }\end{array}$ & $\begin{array}{c}(5) \\
\text { Spanish }\end{array}$ \\
\hline Schooling & $\begin{array}{c}0.0540 * * * \\
(0.0005)\end{array}$ & $\begin{array}{c}0.1090 * * * \\
(0.0020)\end{array}$ & $\begin{array}{c}0.0424^{* * *} \\
(0.0006)\end{array}$ & $\begin{array}{c}0.0531 * * * \\
(0.0020)\end{array}$ & $\begin{array}{c}0.0238 * * * \\
(0.0009)\end{array}$ \\
\hline Language & $\begin{array}{c}0.2003 * * * \\
(0.0033)\end{array}$ & $\begin{array}{c}0.2027 * * * \\
(0.0277)\end{array}$ & $\begin{array}{c}0.1902 * * * \\
(0.0033)\end{array}$ & $\begin{array}{c}0.1386 * * * \\
(0.0156)\end{array}$ & $\begin{array}{c}0.1839 * * * \\
(0.0034)\end{array}$ \\
\hline Married Spouse Present & $\begin{array}{c}0.1916 * * * \\
(0.0028)\end{array}$ & $\begin{array}{c}0.2552 * * * \\
(0.0086)\end{array}$ & $\begin{array}{c}0.1662 * * * \\
(0.0029)\end{array}$ & $\begin{array}{c}0.1641 * * * \\
(0.0125)\end{array}$ & $\begin{array}{c}0.1544 * * * \\
(0.0032)\end{array}$ \\
\hline Experience & $\begin{array}{c}0.0089 * * * \\
(0.0005)\end{array}$ & $\begin{array}{c}0.0007 \\
(0.0016)\end{array}$ & $\begin{array}{c}0.0145^{* * * *} \\
(0.0006)\end{array}$ & $\begin{array}{c}0.0036 \\
(0.0022)\end{array}$ & $\begin{array}{c}0.0142 * * * \\
(0.0006)\end{array}$ \\
\hline Experience Squared & $\begin{array}{c}-0.0001^{* * *} \\
(0.0000)\end{array}$ & $\begin{array}{l}-0.0001^{*} \\
(0.0000)\end{array}$ & $\begin{array}{c}-0.0002^{* * *} \\
(0.0000)\end{array}$ & $\begin{array}{l}-0.0001^{*} \\
(0.0000)\end{array}$ & $\begin{array}{c}-0.0002 * * * \\
(0.0000)\end{array}$ \\
\hline South & $\begin{array}{c}-0.0589 * * * \\
(0.0027)\end{array}$ & $\begin{array}{c}-0.0875^{* * *} \\
(0.0077)\end{array}$ & $\begin{array}{c}-0.0536 * * * \\
(0.0029)\end{array}$ & $\begin{array}{l}-0.0035 \\
(0.0120)\end{array}$ & $\begin{array}{c}-0.0509 * * * \\
(0.0031)\end{array}$ \\
\hline Year Since Migration & $\begin{array}{c}0.0139 * * * \\
(0.0004)\end{array}$ & $\begin{array}{c}0.0216 * * * \\
(0.0013)\end{array}$ & $\begin{array}{c}0.0149 * * * \\
(0.0004)\end{array}$ & $\begin{array}{c}0.0283 * * * \\
(0.0022)\end{array}$ & $\begin{array}{c}0.0140 * * * \\
(0.0005)\end{array}$ \\
\hline YSM Squared & $\begin{array}{c}-0.0001^{* * *} \\
(0.0000)\end{array}$ & $\begin{array}{c}-0.0003 * * * \\
(0.0000)\end{array}$ & $\begin{array}{c}-0.0001^{* * * *} \\
(0.0000)\end{array}$ & $\begin{array}{c}-0.0003^{* * *} \\
(0.0001)\end{array}$ & $\begin{array}{c}-0.0001^{* * *} \\
(0.0000)\end{array}$ \\
\hline Ln Weeks Worked & $\begin{array}{c}0.9888 * * * \\
(0.0052)\end{array}$ & $\begin{array}{c}1.0755^{* * *} \\
(0.0148)\end{array}$ & $\begin{array}{c}0.9708^{* * *} \\
(0.0055)\end{array}$ & $\begin{array}{c}1.0225^{* * *} \\
(0.0210)\end{array}$ & $\begin{array}{c}0.9418 * * * \\
(0.0061)\end{array}$ \\
\hline Protestant Missionary & $\begin{array}{c}-0.2238 * * * \\
(0.0149)\end{array}$ & $\begin{array}{c}0.1032 * * * \\
(0.0196)\end{array}$ & $\begin{array}{c}-0.3292^{* * * *} \\
(0.0288)\end{array}$ & $\begin{array}{c}-0.2500 * * * \\
(0.0594)\end{array}$ & $\begin{array}{c}-0.5103^{* * *} \\
(0.0455)\end{array}$ \\
\hline Protestant*Schooling & $\begin{array}{c}0.0201 * * * \\
(0.0011)\end{array}$ & $\begin{array}{c}-0.0071 * * * \\
(0.0013)\end{array}$ & $\begin{array}{c}0.0342 * * * \\
(0.0019)\end{array}$ & $\begin{array}{c}0.0293 * * * \\
(0.0036)\end{array}$ & $\begin{array}{c}0.0556 * * * \\
(0.0035)\end{array}$ \\
\hline Protestant*YSM & $\begin{array}{c}-0.0013^{* * *} \\
(0.0002)\end{array}$ & $\begin{array}{c}-0.0009 * * \\
(0.0003)\end{array}$ & $\begin{array}{c}-0.0029 * * * \\
(0.0004)\end{array}$ & $\begin{array}{l}-0.0025^{*} \\
(0.0010)\end{array}$ & $\begin{array}{l}-0.0006 \\
(0.0010)\end{array}$ \\
\hline Constant & $\begin{array}{c}5.2830 * * * \\
(0.0215)\end{array}$ & $\begin{array}{c}4.3396 * * * \\
(0.0677)\end{array}$ & $\begin{array}{c}5.3801 * * * \\
(0.0233)\end{array}$ & $\begin{array}{c}5.1089 * * * \\
(0.0877)\end{array}$ & $\begin{array}{c}5.6607 * * * \\
(0.0270)\end{array}$ \\
\hline Observations & 415,061 & 64,052 & 351,009 & 26,343 & 263,437 \\
\hline R-squared & 0.4057 & 0.4082 & 0.3967 & 0.3855 & 0.3859 \\
\hline Adj R-sq & 0.406 & 0.408 & 0.397 & 0.385 & 0.386 \\
\hline Mean & 10.27 & 10.66 & 10.20 & 10.43 & 10.11 \\
\hline Standard Deviation & 0.896 & 0.987 & 0.862 & 0.924 & 0.799 \\
\hline
\end{tabular}

Robust standard errors in parentheses

$* * * \mathrm{p}<0.001, * * \mathrm{p}<0.01, * \mathrm{p}<0.05$

Year fixed effects variables included, but not shown in Table

Notes: Foreign-born persons age 25 to 64 years who worked in the prior year.

Source: U.S. Bureau of the Census, American Community Survey, PUMS, 2005-09 
Table A-14: Analysis of Earnings Among Foreign-Born Adult Females, by Origin Country Colonial Heritage: Protestant Missionaries Only

ACS 2005-09

(Dependent Variable: Natural Logarithm of Earnings, in 2009 dollars)

\begin{tabular}{|c|c|c|c|c|c|}
\hline VARIABLES & $\begin{array}{l}(1) \\
\text { All } \\
\end{array}$ & $\begin{array}{c}(2) \\
\text { UK/US }\end{array}$ & $\begin{array}{c}(3) \\
\text { Non UK/US }\end{array}$ & $\begin{array}{c}(4) \\
\text { French }\end{array}$ & $\begin{array}{c}(5) \\
\text { Spanish }\end{array}$ \\
\hline Schooling & $\begin{array}{c}0.0628 * * * \\
(0.0006)\end{array}$ & $\begin{array}{c}0.0963 * * * \\
(0.0023)\end{array}$ & $\begin{array}{c}0.0544 * * * \\
(0.0008)\end{array}$ & $\begin{array}{c}0.0410 * * * \\
(0.0021)\end{array}$ & $\begin{array}{c}0.0414^{* * *} \\
(0.0011)\end{array}$ \\
\hline Language & $\begin{array}{c}0.2512 * * * \\
(0.0041)\end{array}$ & $\begin{array}{c}0.1649 * * * \\
(0.0240)\end{array}$ & $\begin{array}{c}0.2439 * * * \\
(0.0042)\end{array}$ & $\begin{array}{c}0.1538 * * * \\
(0.0159)\end{array}$ & $\begin{array}{c}0.2674 * * * \\
(0.0047)\end{array}$ \\
\hline Married Spouse Present & $\begin{array}{c}0.0331 * * * \\
(0.0033)\end{array}$ & $\begin{array}{c}0.0114 \\
(0.0087)\end{array}$ & $\begin{array}{c}0.0284 * * * \\
(0.0035)\end{array}$ & $\begin{array}{c}0.0424 * * \\
(0.0139)\end{array}$ & $\begin{array}{c}0.0243 * * * \\
(0.0040)\end{array}$ \\
\hline Experience & $\begin{array}{l}-0.0015^{*} \\
(0.0006)\end{array}$ & $\begin{array}{c}-0.0067 * * * \\
(0.0016)\end{array}$ & $\begin{array}{l}0.0016^{*} \\
(0.0007)\end{array}$ & $\begin{array}{c}-0.0142 * * * \\
(0.0023)\end{array}$ & $\begin{array}{c}0.0063 * * * \\
(0.0008)\end{array}$ \\
\hline Experience Squared & $\begin{array}{c}0.0000 * * * \\
(0.0000)\end{array}$ & $\begin{array}{c}0.0001 * * * \\
(0.0000)\end{array}$ & $\begin{array}{l}-0.0000 \\
(0.0000)\end{array}$ & $\begin{array}{c}0.0002 * * * \\
(0.0000)\end{array}$ & $\begin{array}{c}-0.0001^{* * * *} \\
(0.0000)\end{array}$ \\
\hline South & $\begin{array}{c}-0.0955^{* * *} \\
(0.0033)\end{array}$ & $\begin{array}{c}-0.0593 * * * \\
(0.0084)\end{array}$ & $\begin{array}{c}-0.1020 * * * \\
(0.0035)\end{array}$ & $\begin{array}{c}-0.0399 * * \\
(0.0131)\end{array}$ & $\begin{array}{c}-0.1091^{* * *} \\
(0.0040)\end{array}$ \\
\hline Year Since Migration & $\begin{array}{c}0.0183 * * * \\
(0.0005)\end{array}$ & $\begin{array}{c}0.0202 * * * \\
(0.0014)\end{array}$ & $\begin{array}{c}0.0184 * * * \\
(0.0005)\end{array}$ & $\begin{array}{c}0.0319 * * * \\
(0.0023)\end{array}$ & $\begin{array}{c}0.0150 * * * \\
(0.0006)\end{array}$ \\
\hline YSM Squared & $\begin{array}{c}-0.0002 * * * \\
(0.0000)\end{array}$ & $\begin{array}{c}-0.0002 * * * \\
(0.0000)\end{array}$ & $\begin{array}{c}-0.0002^{* * *} \\
(0.0000)\end{array}$ & $\begin{array}{c}-0.0004^{* * *} \\
(0.0001)\end{array}$ & $\begin{array}{c}-0.0002^{* * * *} \\
(0.0000)\end{array}$ \\
\hline Ln Weeks Worked & $\begin{array}{c}1.0666^{* * * *} \\
(0.0040)\end{array}$ & $\begin{array}{c}1.1328 * * * \\
(0.0119)\end{array}$ & $\begin{array}{c}1.0565^{* * * *} \\
(0.0043)\end{array}$ & $\begin{array}{c}1.0419 * * * \\
(0.0184)\end{array}$ & $\begin{array}{c}1.0379 * * * \\
(0.0047)\end{array}$ \\
\hline Kids & $\begin{array}{c}-0.0426 * * * \\
(0.0035)\end{array}$ & $\begin{array}{c}0.0009 \\
(0.0093)\end{array}$ & $\begin{array}{c}-0.0546^{* * *} \\
(0.0038)\end{array}$ & $\begin{array}{l}-0.0244 \\
(0.0144)\end{array}$ & $\begin{array}{c}-0.0588^{* * * *} \\
(0.0043)\end{array}$ \\
\hline Protestant Missionary & $\begin{array}{c}-0.2153^{* * *} \\
(0.0149)\end{array}$ & $\begin{array}{l}-0.0368 \\
(0.0203)\end{array}$ & $\begin{array}{c}-0.4565 * * * \\
(0.0385)\end{array}$ & $\begin{array}{c}-0.5370 * * * \\
(0.0949)\end{array}$ & $\begin{array}{c}-0.6360 * * * \\
(0.0536)\end{array}$ \\
\hline Protestant*Schooling & $\begin{array}{c}0.0178 * * * \\
(0.0010)\end{array}$ & $\begin{array}{l}0.0026 * \\
(0.0013)\end{array}$ & $\begin{array}{c}0.0331 * * * \\
(0.0027)\end{array}$ & $\begin{array}{c}0.0394 * * * \\
(0.0061)\end{array}$ & $\begin{array}{c}0.0542 * * * \\
(0.0039)\end{array}$ \\
\hline Protestant*YSM & $\begin{array}{l}-0.0003 \\
(0.0002)\end{array}$ & $\begin{array}{l}-0.0004 \\
(0.0003)\end{array}$ & $\begin{array}{l}-0.0000 \\
(0.0005)\end{array}$ & $\begin{array}{l}-0.0014 \\
(0.0013)\end{array}$ & $\begin{array}{c}0.0018 \\
(0.0010)\end{array}$ \\
\hline Constant & $\begin{array}{c}4.7347^{* * * *} \\
(0.0183)\end{array}$ & $\begin{array}{c}4.2369 * * * \\
(0.0615)\end{array}$ & $\begin{array}{c}4.8458 * * * \\
(0.0208)\end{array}$ & $\begin{array}{c}5.2194 * * * \\
(0.0813)\end{array}$ & $\begin{array}{c}4.9778^{* * *} \\
(0.0242)\end{array}$ \\
\hline Observations & 325,280 & 50,634 & 274,646 & 22,713 & 194,598 \\
\hline R-squared & 0.4800 & 0.4417 & 0.4805 & 0.3901 & 0.5008 \\
\hline Adj R-sq & 0.480 & 0.441 & 0.480 & 0.390 & 0.501 \\
\hline Mean & 9.897 & 10.22 & 9.838 & 10.01 & 9.747 \\
\hline Standard Deviation & 1.020 & 1.018 & 1.009 & 0.972 & 0.979 \\
\hline
\end{tabular}

Robust standard errors in parentheses

*** $\mathrm{p}<0.001, * * \mathrm{p}<0.01, * \mathrm{p}<0.05$

Year fixed effects variables included, but not shown in Table 